Aleksandra Brzemia-Bonarek

ks. Szymon Drzyżdżyk

\title{
OD CHRZTU W IMIĘ JEZUSA DO CHRZTU W IMIĘ TRÓJCY ŚWIĘTEJ
}

Sakrament chrztu ustanowił sam Chrystus i polecił go udzielać wszystkim, którzy w Niego uwierzą (Mt 28, 19; Mk 16, 16). W Ewangelii św. Mateusza (Mt 28, 19-20) znajdują się bezpośrednie wskazówki dotyczące wymaganej formuły chrztu: „Idźcie więc i nauczajcie wszystkie narody, udzielając im chrztu w imię Ojca i Syna, i Ducha Świętego". Nauczanie Kościoła określa warunki, które należy spełnić, aby chrzest był ważny. Wymagane są: właściwa forma (trzykrotne polanie wodą lub zanurzenie w niej wraz z wypowiedzeniem słów: „NN, ja ciebie chrzczę w imię Ojca i Syna, i Ducha Świętego"); właściwa materia (woda naturalna); właściwa intencja czynienia tego, co chce Kościół. Normy te nie dotyczą tylko wspólnoty katolickiej, lecz większości chrześcijańskiego świata i stąd wynika wzajemne uznawanie chrztu przez Kościół katolicki i inne wspólnoty chrześcijańskie ${ }^{1}$. Ist-

1 W Polsce wzajemną ważność chrztu świętego udzielonego przez duchownego w formie trynitarnej podpisały 23 stycznia 2000 roku następujące wspólnoty: Kościół ewangelicko-augsburski, Kościół ewangelicko-metodystyczny, Kościół ewangelicko-reformowany, Kościół polskokatolicki, Polski Autokefaliczny Kościół Prawosławny, Starokatolicki Kościół Mariawitów, Kościół katolicki. Punkt pierwszy tego dokumentu brzmi: „Chrzest jest z wody i Ducha Świętego; udziela się go w imię Ojca i Syna, i Ducha Świętego. Chrzest jednoczy ochrzczonego z Chrystusem, chrześcijan między sobą. [...]". Sakrament Chrztu znakiem jedności. Deklaracja Kościotów w Polsce na progu Trzeciego Tysiaclecia, Warszawa 2000, www.ekumenia.pl/czytelnia/dokumenty-ekumeniczne/sakrament-chrztu-znakiem-jednosci/ (19.12.2014). 
nieją jednak również związki wyznaniowe, które nie chrzczą swoich wiernych według formuły trynitarnej. Do takich wspólnot należą na przykład Świadkowie Jehowy lub zgrupowani głównie w USA pentekostaliści („Jesus Only Pentecostal Church”) i mormoni. Kościół katolicki, Kościoły prawosławne i ewangelickie nie uznają takich osób za chrześcijan, nawet jeśli one same tak o sobie myślą i takie przekonanie wyrażają.

Wydawać by się mogło, że kwestia formuły chrztu, której podstawa jest tak jednoznacznie zakotwiczona w Mateuszowej Ewangelii, nie powinna wzbudzać kontrowersji. Tymczasem również współcześnie daje się zaobserwować błędne praktyki pojawiające się raz po raz także wewnątrz wspólnot chrześcijańskich. W 1990 roku w amerykańskim roczniku kanonistycznym „Roman Replies and CLSA Advisory Opinions" poruszono kwestię powstałą na skutek zaistnienia konkretnych faktów spowodowanych pragnieniem uniknięcia maskulinizacji Boga na poziomie lingwistycznym ${ }^{2}$. Podczas wypowiadania formuły chrztu imię Boga Ojca zastąpiono terminem "Stwórca" (Creator), imię Syna terminem „Wyzwoliciel” (Liberator) zaś imię Ducha Świętego terminem „Odkupiciel” lub „Dający Wsparcie Opiekun" (Redeemer, Sustainer). Na skutek pojawiających się wśród Kościołów chrześcijańskich przypadków chrztów udzielanych samowolnie przez szafarza w „swobodnej” formie trynitarnej, problem ten - $\mathrm{w}$ formie zapytania - pojawił się $\mathrm{w}$ tym samym periodyku naukowym w 2006 roku3 $^{3}$. Równocześnie na forum akademickim wznowiono dyskusję, która swe początki miała już w pierwszych wiekach chrześcijaństwa, a dotyczyła ważności chrztu udzielonego przy użyciu innych słów niż ,ja ciebie chrzczę w imię Ojca i Syna, i Ducha Świętego", szczególnie w kontekście właściwej intencji szafarza ${ }^{4}$. Ostatecznie 1 lutego 2008 roku Kongregacja Doktryny Wiary

2 [b. a.], ... to avoid using masculine language of God, „Roman Replies and CLSA Advisory Opinions" [dalej: RR] 1990, s. 92.

3 RR 2006, s. 23-24.

4 Na przykład takiej formuły chrztu: „I baptize you in the name of God the Ground, God the Logos and God the Spirit". Już w starożytności niektóre sekty gnostyckie, posługując się „innymi formułami trynitarnymi”, chrzciły „w imię nieznanego Ojca wszystkiego, w Prawdę, Matkę wszystkich rzeczy, w Tego, który zstąpił na Jezusa dla jedności, odkupienia i wspólnoty mocy". Por. Ireneusz z Lyonu, Adversus haereses I, 21, 3, texte et traduction par A. Rousseau, L. Doutreleau, Paris 1979, s. 298-299 (Sources Chrétiennes, 264). 
wypowiedziała się oficjalnie o nieważności następujących formuł chrzcielnych: „I baptize you in the name of the Creator, and of the Redeemer, and of the Sanctifier”, „I baptize you in the name of the Creator, and of the Liberator, and of the Sustainer"5.

Zasygnalizowane tytułem wstępu zagadnienie formy chrztu jest znacznie szersze i w przeszłości było przedmiotem dyskusji teologów ze względu na znajdujące się w Dziejach Apostolskich wyraźne wzmianki o chrzcie „w imię Jezusa” (Dz 2, 38) oraz głosy podające w wątpliwość, już od czasów reformacji, pierwotne trynitarne brzmienie zakończenia Ewangelii według św. Mateusza (Mt 28, 19-20).

W połowie XIX wieku w teologii protestanckiej pojawiła się hipoteza, że w pierwszych wiekach chrześcijaństwa istniały obok siebie dwa różne ryty chrzcielne: „w imię Jezusa” oraz „w imię Ojca i Syna, i Ducha Świętego". Myśl ta była rezultatem analizy i interpretacji dokumentów wczesnochrześcijańskich oraz badań nad oryginalnością niektórych manuskryptów biblijnych, w tym szczególnie możliwą interpolacją w obrębie perykopy Mt 28, 19-20. W pierwszych siedmiu dekadach XX wieku w środowisku naukowym europejskich badaczy Nowego Testamentu można było zauważyć polaryzację stanowisk. Dało się wyodrębnić obóz „konserwatywny” - optujący za poglądem, że w perykopie Mt 28, 19-20 zawarta jest formuła chrzcielna rzeczywiście wypowiedziana w brzmieniu trynitarnym przez Chrystusa do apostołów, oraz „liberalny” - dopuszczający równoległe istnienie w pierwszych wiekach chrześcijaństwa dwóch rytów chrzcielnych: starszego - chrystologicznego oraz drugiego - trynitarnego, historycznie późniejszego, lecz zdecydowanie bardziej ekspansywnego. Trzeba zauważyć, że pierwotnego pochodzenia trynitarnej formuły chrzcielnej szczególnie silnie bronił Kościół katolicki. Od lat 70. ubiegłego wieku obserwuje się złagodzenie stanowisk obu obozów naukowych oraz posiłkowanie się $\mathrm{w}$ analizach badawczych osiągnięciami nauk o języku, historii starożytności, czy nawet naukami przyrodniczymi (chemiczne badania oryginalności manuskryptów, ustalanie wieku barwnika, jakim były pisane teksty, a także wykorzystanie mikroskopowej archeologii botanicznej). Dyskusja akademicka toczy się zatem do dziś, jednakże z mniejszym ładunkiem emocjonalnym,

Congregatio pro Doctrina Fidei, Responsa ad proposita dubia de validitate baptismatis, „Notitiae” 45 (2008) nr 3-4, s. 135. 
gdyż niewielka ilość danych historiograficznych nakazuje rozważne formułowanie hipotez tłumaczących fenomen relacji formuły chrystologicznej do trynitarnej.

Globalne rozproszenie stanowisk współczesnych badaczy w różnych periodykach naukowych oraz licznych zwartych publikacjach utrudnia regularne śledzenie tego zagadnienia i jego ewolucji w teologii ${ }^{6}$. Wielu autorów podręczników dla studentów i monografii uzupełniających ich późniejszą wiedzę, a traktujących o rozwoju doktryny Kościoła, jedynie przelotnie poświęca uwagę temu interesującemu problemowi. Stąd słuszne wydaje się bliższe omówienie kwestii.

Niniejsze rozważania mają charakter przeglądowy i stanowią próbę usystematyzowania stanowisk i osiągnięć teologów w zakresie następujących pytań: Czy apostołowie rzeczywiście praktykowali udzielanie chrztu w imię Jezusa? Jeśli takie ordo miało w pierwotnym Kościele miejsce, to czy formuła chrztu „w imię Ojca i Syna, i Ducha Świętego" stała się kanonem w odpowiedzi na rozwój dogmatyki, w szczególności po przyjęciu na Soborze w Nicei obowiązującego wyznania wiary, czy też stało się tak wcześniej? Kiedy i dlaczego nastąpiło definitywne przejście od formuły chrystologicznej do formuły trynitarnej?

Artykuł składa się z trzech części. W pierwszej zostanie przedstawiona historia debaty nad formułą chrztu w czasach apostolskich wraz z argumentacją poszczególnych uczestników trwającej ponad wiek dyskusji. Część druga będzie analizą tekstów poapostolskich pod kątem informacji na temat chrztu. Ostatnia będzie poświęcona kwestii credo ze względu na ścisły związek pomiędzy wyznaniem wiary a ważnością lub nieważnością chrztu.

\section{Chrzest w czasach apostołów. Historia debaty}

Zakończenie Ewangelii według św. Mateusza (Mt 28, 19-20) zawiera nakaz misyjny i wyraża pragnienie Jezusa, by chrzest był udzielany w imię Ojca, Syna i Ducha św. Jest to formuła trynitarna. Tymczasem

6 Autorzy składają podziękowanie księdzu prof. Januszowi Kowalowi SJ z Papieskiego Uniwersytetu Gregoriańskiego w Rzymie za przesłanie niedostępnej w Polsce literatury przedmiotu pomocnej przy pisaniu niniejszego artykułu. 
w Dziejach Apostolskich nie znajdujemy odwołania do chrztu „w imię Ojca, Syna i Ducha Świętego", lecz mowa jest o chrzcie w imię Jezusa Chrystusa: „i niech każdy z was przyjmie chrzest w imię Jezusa Chrystusa” (Dz 2, 38); „Byli jedynie ochrzczeni w imię Pana Jezusa” (Dz 8, 16); „I rozkazał ochrzcić ich w imię Jezusa Chrystusa” (Dz 10, 48); „przyjęli chrzest w imię Pana Jezusa” (Dz 19, 5).

W latach 60. XIX stulecia francuski teolog i historyk Kościoła Edmond de Pressencé w dziele Early years of the Christian Church (przekład angielski z 1870 roku) ${ }^{7}$, pisząc o Kościele I wieku, jednoznacznie wypowiedział się za istnieniem formuły chrzcielnej „w imię Pana Jezusa”. Ten protestancki badacz definiował chrzest w czasach apostolskich jako uroczysty znak nawrócenia ${ }^{8}$, zwracając uwagę, iż w Nowym Testamencie brak jest przykładów kompletnych formuł chrztu: „There is no example in the New Testament of the employment of the complete formula of baptism" ${ }^{\prime}$. Czy tym zdaniem autor chciał wyrazić przekonanie, że uważa perykopę 28, 19-20 Ewangelii św. Mateusza za fragment dodany do pierwotnej wersji tego tekstu? Wydaje się, że wobec zbyt małej próbki analizowanej twórczości naukowej Edmonda de Pressencéa pytanie to musi pozostać otwarte. Wszelako można przyjąć, że znane mu były datowane przed jego monumentalną monografią komentarze protestanckich badaczy Pisma Świętego (jak np. Roberta Younga, Abrahama Tellera ${ }^{10}$ ), którzy przychylali się do uznania zakończenia Ewangelii św. Mateusza za interpolację. W opisie chrztu u pierwszych chrześcijan autor wskazywał na nierozerwalny związek między przyjęciem sakramentu przez konwertytę a publicznym złożeniem przez niego przed otrzymaniem chrztu krótkiego wyznania wiary, które nie było jeszcze sformalizowane pod względem terminologicznym ${ }^{11}$. Praktyka taka, według

7 E. de Pressencé, Early years of the Christian church. The apostolic era, tłum. na j. ang. A. Harwood, vol. II, New York 1870.

8 "Administered in the name of the Lord Jesus as a solemn sign of conversion, it had all the value of an explicit confession of the Christian faith". E. de Pressencé, Early years..., dz. cyt., s. 375.

$9 \quad$ E. de Pressencé, Early years..., dz. cyt., s. 375, przypis *.

10 Poglądy tych badaczy zostaną zreferowane w dalszej części tekstu.

11 Podając jako fakt ścisłą relację między chrztem a publicznie wyrażoną wiarą katechumena, de Pressencé prezentuje równocześnie bardzo skrajne, obecnie mniejszościowe w chrześcijańskim świecie stanowisko wobec praktyki chrztu niemowląt. Twierdzi bowiem, że wymogi złożenia wyznania wiary i aktywnego uczestnictwa 
tego badacza, była bardzo popularna w II wieku. De Pressencé stawia więc tezę, że pojawiła się ona wcześniej, już w I wieku. Odnośnie do wyznania wiary teolog ten stał na stanowisku, że późniejszy Skład apostolski jest niczym innym, jak tylko pierwotną formułą chrzcielną, do której w kolejnych dziesięcioleciach dodawano poszczególne sformułowania, aż jej treść w IV wieku stała się obowiązującą regułą i symbolem wiary.

W o dekadzie młodszej od pierwszego wydania książki Edmonda de Pressencé’a XIX-wiecznej katolickiej Encyklopedii teologicznej ${ }^{12}$ wyrażono pogląd, iż Kościół „od zawsze” przywiązywał wielką wagę do tego, wedle jakiej formuły zostali ochrzczeni heretycy, odmawiając uznania ważności ich chrztu, jeśli formuła wypowiadana przez szafarza sakramentu nie była wyrażona $\mathrm{w}$ formie trynitarnej. Zagadnienie to ujęto następująco: „chociaż od czasów arian w Kościele pierwotnym pojawiały się dyskusje nad równorzędnością formuły chrztu «w imię Boga Ojca» lub «w imię Jezusa» obecnie nie ma wątpliwości, że do ważności chrztu wymagana jest inwokacja do Trzech Osób Boskich"13. I faktycznie, we wspomnianej encyklopedii teologicznej z XIX wieku, której hasła mają konwencję krótkiego artykułu, nie znajdziemy dodatkowej wzmianki o „chrzcie w imię Jezusa”.

W 1901 roku na łamach Zeitschrift für Neutestamentlich Wissenchaft $^{14}$ ukazał się artykuł Fredericka Cornwallisa Conybeare'a, brytyjskiego orientalisty i teologa związanego ze środowiskiem uniwersyteckim w Oxfordzie, który wzbudził żywe zainteresowanie ówczesnego środowiska naukowego badającego pierwsze wieki chrześcijaństwa - i to zarówno wśród katolików, jak i protestantów.

Wywody Conybeare'a, będące rezultatem jego badań nad wydaniami krytycznymi starożytnych autorów chrześcijańskich, począwszy od Rufina z Akwilei, a skończywszy na współczesnych patrologach

w dialogowej formie chrztu wykluczały dopuszczenie małych dzieci do tego sakramentu (por. E. de Pressencé, Early years..., dz. cyt., s. 376).

12 Encyclopédiè théologie, t. 33, Dictionnaire de théologie dogmatique, vol. I, ed. M. Pierrot, J. P. Migne, Paris 1850, s. 483-500.

13 „Le manière que le baptême conféré au nom de Dieu, au nom de Jésus-Christ serai cencé nul. L'Ėglise fa toujous très attentive à examiner si les hèretiques changeaint quelque chose à la formule de ce sacrament". Encyclopédiè théologie, vol. 33, dz. cyt., s. 485 [tłum. własne autorów].

14 F. C. Conybeare, The Eusebian form of the text of Matthew 28:19, „Zeitschrift für Neutestamentlich Wissenchalf" 1901, s. 275-288. 
i biblistach ${ }^{15}$, doprowadziły do interesującej i odkrywczej konkluzji. Analizując dorobek literacki Euzebiusza, Conybeare zauważył, że w swych wcześniejszych pracach biskup z Cezarei cytował inną, krótszą wersję perykopy 28, 19-20 z Ewangelii św. Mateusza, a w tekstach późniejszych (powstałych po Soborze z Nicei) - znaną obecnie wersję „kanoniczną". W szczególnie widoczny sposób miało to miejsce w V księdze Teofanii Euzebiusza, gdzie perykopa Mt 28, 19-20 jest cytowana trzy razy (Teophania V, 17, 46, 49) ${ }^{16}$. Po nakazie misyjnym skierowanym przez Chrystusa do uczniów: „idźcie i nauczajcie wszystkie narody" brakowało odwołania do formuły trynitarnej: „udzielając im chrztu w imię Ojca i Syna, i Ducha Świętego". Zamiast tego Euzebiusz używał zwrotu: „[idźcie i nauczajcie wszystkie narody - przyp. aut.] chrzcząc je w Moje imię". Właśnie ta tak zwana „krótka forma euzebiuszowa” („short Eusebian form”) stała się przede wszystkim źródłem licznych dyskusji, a postawione przez Conybeare'a na początku XX wieku hipotezy są przywoływane - szczególnie przez pisarzy anglosaskich -jako „klasyczne” we współczesnych publikacjach z dziedziny historii rozwoju dogmatu.

W dalszej części badań Conybeare starannie przeanalizował komentarz Rufina z Akwilei do Homilii Orygenesa i zauważył, że ten późnoantyczny tłumacz sam napisał o swoich problemach z uzupełnieniem brakujących części tekstu w dziełach Orygenesa. Rufin znany jest z pięknych językowo przekładów z języka greckiego, oddających zamysł i „ducha” autora tekstu, ale nie z przekładów literalnych. Stąd brytyjski teolog podał w wątpliwość zasadność bezwarunkowego przyjmowania wierności tego IV-wiecznego przekładu. Dokonując analizy logicznej niewielkiego fragmentu Homilii VIII Orygenesa (n. 4), który powołuje się na zakończenie Ewangelii św. Mateusza („cum ergo venimus ad gratiam baptismi, universis aliis diis et dominis renuntiantes, Solum confitemur Deum Patrem et Filium et

15 Conybeare na potrzeby swoich badań przeanalizował zachowane oryginalne fragmenty dzieł Euzebiusza, posiłkował się również tłumaczeniem Teofanii dokonanym przez Samuela Lee, redaktora angielskiego wydania krytycznego tegoż dzieła (S. Lee, Eusebius, bishop of Cesarea in the Teophania, Cambridge, 1843), powstałego w oparciu o manuskrypt zdeponowany w Muzeum Brytyjskim i datowany na rok 411.

16 F. Conybeare posiłkował się wydaniami pochodzącymi z kolekcji Patrologia Latina pod redakcją Migne’a, ale na potrzeby artykułu cytował Euzebiusza we wspomnianym tłumaczeniu angielskim Samuela Lee. 
Spiritum Sanctum. Sed hoc confitentes, nisi toto corde diligamus Dominum Deum nostrum... non sumus effecti pars Domini... et Dominum, aad quem configumus, propitium non effecimus, quem non ex toto et integro corde diligimus"17), Conybeare zadał pytanie, dlaczego słowo "Dominum” zostało zamieszczone zaraz po bezpośredniej inwokacji do Trójcy Świętej i postawił tezę, że trynitarne formuły stojące w tekście obok opisów silnie chrystologicznych pochodzą w rzeczywistości od Rufina i są późniejszymi wersjami spornego fragmentu perykopy ${ }^{18}$. Brytyjski naukowiec przyznał, że w innych dziełach Orygenesa, np. w komentarzu do Ewangelii Janowej, znajdują się również oryginalne (to jest: pochodzące od niego) trynitarne wezwania chrzcielne. Jego zdaniem należy przyjąć, iż zarówno Euzebiusz, jak i Orygenes korzystali z nieznanej w północnym basenie Morza Śródziemnego starej (prawdopodobnie syryjskiej) kopii Ewangelii św. Mateusza, mimo że znane były im również inne kopie Nowego Testamentu będące w ówczesnym obiegu. Tym niemniej liczne odwołania do krótszego zakończenia Mateuszowej Ewangelii pozwalają przyjąć, że wezwanie do Trójcy Świętej pochodzące z Mt 28, 19-20 jest późniejszym (mniej więcej o jeden wiek w stosunku do czasu powstania tej Ewangelii) tekstem przyjętym z praktyki liturgicznej (chrzcielnej) Kościoła. Conybeare podaje przedział lat 130-140, czyli czasy na krótko przed narodzinami Tertuliana ${ }^{19}$.

Oryginalność publikacji Conybeare'a nie polegała na tym, że jako pierwszy uznał on zakończenie Ewangelii według św. Mateusza za możliwą interpolację. Takie hipotezy przedstawiali już teologowie publikujący wcześniej od niego, jak Abraham Teller w XVIII wieku podczas dokonywania redakcji i opracowania dzieła Thomasa Burneta De Fide et Officiis Christianorum ${ }^{20}$, a w XIX wieku szkocki biblista i tłumacz z języków oryginalnych Robert Young ${ }^{21}$. Z kolei James Martineau podczas analizy lingwistycznej Mateuszowego tekstu uznał,

17 Conybeare cytował tekst łaciński zamieszczony w tomie 12 z kolekcji Patrologia Latina, ed. J. P. Migne, Paris 1844-1855 (Homilia in Exod. 8, [w:] Origenis Opera Omnia, Paris 1862, s. 288).

18 F. Conybeare, The Eusebian form..., dz. cyt., s. 285.

19 F. Conybeare, The Eusebian form..., dz. cyt., s. 288.

20 T. Burnet, De Fide et Officiis Christianorum, Hale 1786, s. 262.

21 Young's literal translation of the Holy Bible, Edinburgh 1862 (revised version 1887). Robert Young podczas tłumaczenia Mt 28, 19-20 wyodrębnił inną czcionką trynitarną formułę chrzcielną jako prawdopodobną interpolację. 
że Chrystus mówi w tym fragmencie Ewangelii ,językiem kolejnego stulecia" ${ }^{22}$, co zdradza podejrzenie interpolacji tekstu. Współczesny Conybearowi uczony, anglikański teolog Armitage Robinson, w artykule odnoszącym się do chrztu napisanym jako hasło dla Encyclopeadia Biblica uznał, że zakończenie Ewangelii św. Mateusza nie cytuje dosłownie słów Chrystusa, lecz przekłada je na język Kościoła tamtych czasów i terenów (geograficznych) ${ }^{23}$.

U źródła nowatorskości myśli Fredericka Conybeare’a leżała spostrzegawczość badacza i umiejętność analizy, która doprowadziła go do przyjęcia hipotezy o nieautentyczności fragmentu perykopy Mt 28, 19-20 wyinterpretowanej z badań porównawczych nad tekstami Euzebiusza. Everlett Ferguson w książce Baptism in the early Church. History, theology and liturgy in the first five centuries $^{24}$ również opisuje historyczną dyskusję, jaką rozpoczął Conybeare swoją „krótką formą euzebiuszową”, wskazując, że historyk z Cezarei w swoich dziełach różnie opisywał nakaz chrzcielny dany apostołom przez Chrystusa, najczęściej pomijając trynitarną formę chrztu, co stało się podstawą do postawienia tezy o istnieniu za jego czasów jakiejś innej wersji Ewangelii św. Mateusza. Współczesny badacz teologii wskazuje, że nowsze badania nad strukturą literacką tekstu rzeczywiście przemawiają za prawdziwością krótkiej formy Mateuszowej Ewangelii w jej zakończeniu ${ }^{25}$, choć jednocześnie nie wyklucza, że rację mogli mieć również ci uczeni, którzy broniąc jedności Mt 28, 19-20 uważali, że Euzebiusz dokonywał parafrazy

22 J. Martineau, The seat of authority in religion, London 1890, s. 515.

23 Por. Encyclopeadia Biblica: A critical dictionary of the literary, political and religion history, the archeology, geography and natural history of the Bible, ed. T. K. Cheyne, J. Sutherland Blacked, Toronto 1899.

24 E. Ferguson, Baptism in the early Church. History, theology and liturgy in the first five centuries, Cambridge 2009, zob. szczególnie strony 133-136.

25 Ferguson powołuje się na badania Hansa Kosmali i Davida Flussera: H. Kosmala, The conclusion of Matthew, "Annual of the Swedish Theological Institute” 4 [1965], s. 132-147; D. Flusser D. The conclusion of Matthew in a New Jewish Christian Source, „Annual of the Swedish Theological Institute” 5 [1966-1967], s. 110-119. Zamieszcza również wyniki przeliczeń użycia „krótkiej formy Mt 28, 19” - 19 razy oraz „kanonicznej" - 5 razy, które w ramach badań nad tekstami Euzebiusza dokonał H. Benedict Green CR w artykule: Matthew 28:19, Eusebius, and the lex orandi, s. 124-141 (obliczenia podane na s. 126), zamieszczonym w księdze pamiątkowej ku czci Henry'ego Chadwicka: The making of orthodoxy, ed. R. Williams, Cambridge 1989 [wersja online: 2009]. 
tego fragmentu Ewangelii ${ }^{26}$. Autor przyznaje też, że za stanowiskiem „trynitarnym” przemawiają argumenty z praktyki Kościoła: wczesnochrześcijańska akceptacja trynitarnej formy chrzcielnej, istnienie formuły trynitarnej w zachowanych manuskryptach Nowego Testamentu oraz fakt, że Ewangelia według św. Mateusza była najbardziej rozpowszechnioną $w$ chrześcijańskim świecie drugiego stulecia ${ }^{27}$.

Bezpośrednią odpowiedzią na artykuł F. Conybeare'a był opublikowany w 1905 roku w „Journal of Theological Studies” artykuł Franklina Henry'ego Chase'a The Lord's command to baptize (St. Matt. XXVIII, 19) z konkluzją utrzymującą, że tekst Ewangelii w swej integralności jest pierwotny i oryginalny ${ }^{28}$. Polemikę z tezami Conybeare'a zawarł Chase na kilkunastu stronach ${ }^{29}$. Przede wszystkim zwrócił uwagę, że Euzebiusz - historyk Kościoła - dysponował w Cezarei wspaniale wyposażoną biblioteką i chociaż domniemanie ogólne o istnieniu od początku dwóch wersji pierwszej Ewangelii nie jest pozbawione podstaw logicznych, to na podstawie dyskusji nad „krótką formą chrzcielną" nie można udowodnić, że niektóre Kościoły starożytne posiłkowały się hebrajską (a raczej aramejską), odmienną wersją Ewangelii św. Mateusza, w której istniała chrystologiczna formuła chrztu, zaś inne Kościoły - wersją grecką, gdzie z kolei wpisane były słowa współcześnie znanej formuły chrztu ${ }^{30}$.

Chase zgodził się z faktem, że Euzebiusz cytował w swoich dziełach część spornego fragmentu Ewangelii. Jego interpretacja tej okoliczności była jednak inna: uważał on, że Euzebiusz dokonał po prostu swobodnego przytoczenia fragmentu Pisma Świętego, uwypuklając

26 Np. metoda dosyć swobodnego cytowania Pisma Świętego przez Euzebiusza. Więcej na ten temat: B. H. Cuneo, The Lord's command to baptise. An historico-critical investigation with special references to the work of Eusebius of Caesarea, Washington 1923, s. 70-110.

27 E. Ferguson, Baptism in the early Church..., dz. cyt., s. 134-135.

28 F. H. Chase, The Lord's command to baptize (St. Matthew XVIII, 19), „Journal of Theological Studies" 1905 nr VI (24), s. 481-512, www.biblicalstudies.org.uk/pdf/ jts/006_481.pdf (12.09.2014).

29 F. H. Chase, The Lord's command to baptize..., dz. cyt., s. 483-499.

30 Na temat "hebrajskich” wersji Mateuszowej Ewangelii obszernie pisze (wraz z podaniem źródeł i opracowań) Warren H. Carrol w swoim dziele Historia chrześcijaństwa, t. 1, Narodziny chrześcijaństwa, tłum. J. Morka, Wrocław 2009, s. 410-411, włącznie z obszernymi przypisami. 
osobę Chrystusa jako centrum nowego życia chrześcijanina; imię „wywyższone ponad wszelkie imię" (Flp 2, 8-11). Posiłkując się Demonstratio Evangelica autorstwa Euzebiusza, gdzie również znalazły się odniesienia do Mt 28, 19, Chase wykazywał, że intencją autora było zwrócenie uwagi odbiorców tekstu na różnice pomiędzy starym prawem Mojżeszowym a prawem Chrystusa, magikami udającymi bóstwo a prawdziwą Boskością Jezusa, hermetycznością Żydów a globalną misyjnością chrześcijan. Dlatego też - argumentował adwersarz Conybeare'a - pomijanie frazy o trynitarnej formule chrztu było efektem zamierzonym i słusznym, służącym zachowaniu logicznej jasności wywodów tego IV-wiecznego biskupa ${ }^{31}$. Chase zdystansował się również od tych tez Conybeare'a, które dotyczyły przedeuzebiuszowskich dowodów nieznajomości formy trynitarnej: świadectwa Justyna Męczennika w 39 rozdziale Dialogu z Żydem Tryfonem. Zwrócił on uwagę, że Justyn w słowach opisujących nawrócenie niektórych Żydów na chrześcijaństwo bliższy jest powoływaniu się na fragmenty Ewangelii św. Łukasza: „w imię Jego głoszone będzie nawrócenie i odpuszczenie grzechów wszystkim narodom, począwszy od Jerozolimy” (Łk 24, 46-48) i św. Marka: „idźcie na cały świat i głoście Ewangelię wszelkiemu stworzeniu! Kto uwierzy i przyjmie chrzest będzie zbawiony" (Mk 16, 17-18), niż Ewangelii św. Mateusza (Mt 28, 19-20). Z kolei analizując Teofanię Euzebiusza, Chase dokonał próby przełożenia "akcentów interpretacyjnych” i w ten sposób doszedł do wniosku, że Euzebiusz chciał zwrócić uwagę czytelnikom na bezwarunkowy nakaz misyjny pochodzący od Chrystusa, nakazujący apostołom, aby głosili Dobrą Nowinę „w imię Chrystusa” ${ }^{32}$. W końcu Chase polemizował również z tezą Conybeare'a dotyczącą możliwych błędów kopistów, dopisków do pierwotnych tekstów Euzebiusza dokonanych przez Sokratesa Scholastyka czy też Euzebiusza z Pamfilii ${ }^{33}$. Chase nie zgodził się z hipotezą, jakoby List Euzebiusza do Kościoła $w$ Cezarei z 325 roku zawierał interpolację w postaci pełnego fragmentu Ewangelii św. Mateusza 28, 19-20. Przeciwnie, uważał, że pozycja Euzebiusza wśród innych biskupów oraz jego wiedza była tak duża, że powszechnie liczono się z jego zdaniem

31 F. H. Chase, The Lord's command to baptize..., dz. cyt., s. 487.

32 F. H. Chase, The Lord's command to baptize..., dz. cyt., s. 492.

33 F. Conybeare, The Eusebian form..., dz. cyt., s. 334. 
i przemyśleniami doktrynalnymi. Nie inaczej musiało być na Soborze w Nicei, tymczasem brak jest jakichkolwiek dowodów świadczących, aby na tym soborze Euzebiusz po raz pierwszy zetknął się z trynitarną formułą chrzcielną znajdującą się bezpośrednio w tekście Nowego Testamentu ${ }^{34}$.

Uwagi Benedicta Greena we wnioskach przywołanego artykułu z 1989 roku Matthew 28:19, Eusebius, and the lex orandi ${ }^{35}$ dotyczące pewnej stagnacji świata teologicznego w badaniach nad chrztem i ożywienia spowodowanego dopiero publikacją Conybeare'a nie są pozbawione racji. Wcześniejsze rozważania teologiczne o charakterze encyklopedycznym zadowalały się asertorycznymi stwierdzeniami o trynitarnej formule chrztu, aby ewentualne wątpliwości wskazywać jako dawne zaszłości historyczne. Jednak dziewięć lat po publikacji hipotezy Conybeare'a o dodanej do Ewangelii św. Mateusza trynitarnej formule chrztu słownik teologiczny Dictionnaire d'archeologie chrétienne et liturgie zagadnieniu formuły chrztu „w imię Jezusa” i obronie tradycji trynitarnej poświęcił kilka osobnych szpalt $\mathrm{w}$ ramach omawiania hasła "chrzest” oraz przedstawił w bibliografii całkiem bogatą literaturę przedmiotu w temacie samej tylko formuły chrztu, powstałą na przełomie lat 1892-1906 ${ }^{36}$.

Stanowisko pośrednie, uwzględniające możliwość interpolacji pierwotnego tekstu zakończenia Ewangelii św. Mateusza, a równocześnie broniące zasadności tradycji katolickiej o chrzcielnej inwokacji do imiennie wypowiadanych Osób Boskich jako wymogu ważności sakramentu, zaprezentował $\mathrm{w}$ swoim artykule The formula of baptism in the early Church Leo F. Miller, teolog katolicki ${ }^{37}$. Najpierw zastrzegł on, że jego publikacja ma charakter dociekań historyka Kościoła i nie jest jej celem podważanie autorytetu Urzędu Nauczycielskiego Kościoła w ustaleniu kryterium określającego wymagania co do ważności formy chrztu. W 1925 roku, a zatem na długo przed

34 „Eusebius expressly asserts that what he insists on in his Letter he had learned in his earliest days". F. H. Chase, The Lord's command to baptize..., dz. cyt., s. 496.

35 H. B. Green, Matthew 28:19, Eusebius, and the Lex Orandi, dz. cyt., w konkluzji.

36 Baptême, [w:] Dictionnaire d'archèologie chrétienne et liturgie, ed. F. Cabrol, vol. II, Paris 1910, s. 338-342; bibliografia na s. 344-346.

37 L. F. Miller, The formula of baptism in the early Church, „The Catholic Historical Review" 10 (1925) nr 4, s. 515-535. Artykuł Millera skupiał się głównie na analizie pism okresu patrystycznego i omówiony zostanie w części poświęconej temu okresowi historii Kościoła. 
soborem watykańskim II, takie założenie bazowe pozwoliło mu uzyskać swobodę naukową $\mathrm{w}$ dociekaniach nad tezami forsowanymi głównie przez teologów oficjalnie uznawanych przez Magisterium Kościoła za heretyków i schizmatyków. Tak „asekurowany” Miller zaprezentował stanowisko, w którym stwierdził, że niemożliwe jest uzyskanie „twardego dowodu" historycznego przemawiającego za istnieniem chrzcielnej formuły trynitarnej jako pierwotnej ${ }^{38}$.

W innym kierunku interpretacyjnym poszedł Hans von Campenhausen. W 1971 roku opublikował on artykuł Taufe auf den Name Jesu? ?9 $^{39}$ w którym dowodził, że słowa „w imię Jezusa” należy rozumieć jako nazwę własną chrześcijańskiego chrztu („chrzest Chrystusowy"), a nie wcześniejszą od trynitarnej chrystologiczną formułę chrzcielną ${ }^{40}$. Campenhausen wskazywał, że nacisk na dodawanie w Dziejach Apostolskich wyrażenia „w imię Jezusa” oznaczał podkreślenie dla chrześcijan pochodzenia żydowskiego inności tego chrztu od znanego ówczesnym i nadal praktykowanego wśród konwertytów z politeizmu chrztu Jana Chrzciciela ${ }^{41}$ oraz innych znanych w starożytności pogańskich ablucji związanych z formą kultu religijnego. W pełnej symbolice starożytności imię odpowiadało istocie człowieka. W Nowym Testamencie jest więc to imię, które wypędza złe duchy (np. Mk 9, 38; Dz 16, 18), które czyni cuda (np. Mk 9, 39; Mt 7, 22; Dz 3, 16), w które będzie głoszone nawrócenie wszystkim narodom (Łk 24, 47), „w którym narody nadzieję pokładać będą” (Mt 12, 21), imię, które gwarantuje spełnienie wszystkich próśb (J 14,13n), i które wreszcie, wzywane, będzie gwarantem zbawienia wiecznego (Jl 3, 5; Dz 2, 21; Rz 10, 13) ${ }^{42}$. Chrzest „w imię Jezusa” oznaczał więc przyjęcie całej substancjalnej wiary chrześcijańskiej, łącznie z wczesnymi trynitarnymi interpretacjami tajemnicy Chrystusa ${ }^{43}$.$$
\text { s. } 1-16 \text {. }
$$

40 Analogicznie wypowiedział się F. H. Chase, The Lord's command to baptism..., dz. cyt., s. 501-502.

${ }^{41}$ Podobnie A. Kavanagh, The shape of baptism, the rite of Christian initiation, Collegeville MN 1991, s. 38.

42 M. Majewski, ImięJezusa, „Posłaniec Serca Jezusowego” 2005 [nr 9] wrzesień, www.psj. net.pl/?0509,artykul,ImieJezusa (10.08.2014).

43 M. Fiedorowicz, Teologia ojców Kościoła: podstawy wczesnochrześcijańskiej refleksji nad wiarą, przekł. W. Szymona, Kraków 2009, s. 215. 
Podzielający te poglądy badacze ${ }^{44}$ dodawali także, że fragmenty Dziejów Apostolskich nie zawierają „wyrażeń technicznych”, czyli formuł chrztu, a jedynie podają informacje o udzielanych przez apostołów chrztach ${ }^{45}$. Z punktu widzenia zasad logiki trzeba też stwierdzić, że fragmenty te nie stoją w sprzeczności z wczesnochrześcijańską doktryną trynitarną ${ }^{46}$. Użycie przez św. Łukasza (autora Dziejów Apostolskich) frazy „chrzest $w$ imię Jezusa” oznaczało rozróżnienie pomiędzy chrztem chrześcijan a chrztem prozelitów żydowskich, zaś bezpośrednie wymienienie imienia Jezusa Chrystusa nad przyjmującym ten sakrament było wyrazem zespolenia go z Synem i obdarzenia go udziałem w Bożej naturze: „Czyż nie wiadomo wam, że my wszyscy, którzyśmy otrzymali chrzest zanurzający w Jezusa Chrystusa, zostaliśmy zanurzeni w Jego śmierć?" (Rz 6, 3). Anselm Grün napisał w jednym ze swoich dzieł: „Kandydat do chrztu miał świadomość, że w Chrystusie otrzymywał nową egzystencję i nową tożsamość" ${ }^{47}$. Dowodem pośrednim przywoływanym przez katolickich teologów początku XX wieku w odpowiedzi na polemiczne stanowiska zwolenników oryginalności „chrztu w imię Jezusa” było przywoływanie perykopy o działalności św. Pawła w Efezie (Dz 19, 1-7), gdy apostoł usłyszawszy, że mieszkańcy tego miasta nie znają Ducha Świętego, zapytał: „Jaki więc chrzest przyjęliście?”48. Dialog ten jest również interesujący ze względu na inną powiązaną z chrztem kwestię: sprawę wyznania wiary. Czasy apostolskie oraz ekspansja chrześcijaństwa w basenie Morza Śródziemnego były źródłem masowych nawróceń ludzi w wieku dorosłym. Wraz z przyjęciem chrztu nowo nawrócony wyznawał wiarę i było to credo z uwzględnieniem Trójcy Świętej ${ }^{49}$.

Nie sposób jednak nie mieć wątpliwości, czy silnie chrystocentryczna teologia św. Pawła odnosząca się do chrztu nie stoi w opozycji do chrztu w formie trynitarnej. Paweł w listach do Rzymian (Rz 6, 3) i do Galatów (Ga 3, 27) pisze o „chrzcie w Chrystusie”. Czy

44 Na przykład protestancki teolog Robert W. Jenson w książce: The Triune God. Systematic theology, vol. I, Oxford 1997, s. 45-46, przychyla się do stanowiska bliskiego poglądowi Campenhausena.

45 J. Crehan SJ, Early Christian baptism and the creed, London 1950, s. 76-78, 156-158.

46 Por. [b. a.], Trinitarian baptism, www.catholic.com/tracts/trinitarian-baptism (10.08.2014).

47 A. Grün OSB, Chrzest. Poczatek nowego życia, tłum. G. Sowiński, Kraków 2005, s. 9.

48 Baptême, [w:] Dictionnaire..., dz. cyt., s. 338.

49 Więcej o związkach reguły wiary z formułą chrztu w dalszej części artykułu. 
jednak można w sensie ścisłym nazwać to formułą chrzcielną? Joachim Gnilka w książce Teologia Nowego Testamentu interpretuje Pawłowe „zanurzenie przez chrzest w Chrystusa” jako oznaczające włączenie w Kościół - Ciało Chrystusa ${ }^{50}$. Przywoływany autor pisze następująco o zastanym przez św. Pawła obrzędzie chrzcielnym w pierwotnym chrześcijaństwie i rozumieniu samego chrztu:

[do elementów rozumienia chrztu należało - przyp. aut.] udzielanie go w wodzie bieżącej, jeśli to tylko było możliwe oraz wypowiedzenie formuły: w imię Jezusa. [...] Udzielanie go w imię Jezusa zakładało, że imię to wypowiadano nad kandydatem do chrztu, ten zaś przyjmował Jezusa, prawdopodobnie w słowach: Panem jest Jezus (Rz 10, 9) ${ }^{51}$.

W innym swoim dziele, Pawet $z$ Tarsu. Apostot $i$ świadek, Joachim Gnilka również mówi o formule chrztu „w imię Jezusa”, lecz tym razem pisze wprost: „chrześcijaństwo Pawła nie zna jeszcze chrztu w imię Ojca i Syna, i Ducha Świętego"52. Niestety, autor nie argumentuje tego stanowiska ani nie odsyła czytelnika do literatury. Nie można więc znaleźć uchwytnych przesłanek przekonujących do poglądu tego wybitnego niemieckiego profesora teologii i historii chrześcijaństwa.

Michael Fiedorowicz w Teologii ojców Kościoła tak pisze o fenomenie chrztu w imię Jezusa:

wzmianki o „chrzcie w imię Jezusa” (Dz 2, 38; 8, 16; Cypr., ep. 73, 4, 1: „in nomine Jesu Christii baptizati”) nie pozwalają na wyciągniecie pewnego wniosku o istnieniu jednoczłonowego wyznania chrystologicznego podczas chrztu lub bezpośrednio po nim. Chrzcielne formuły i wyznania wiary mające trójczłonową strukturę trynitarną są oparte na wczesnych świadectwach. W Nowym Testamencie są one przygotowane przez Mt 28, 19 i Ef 4, 4-6 i mają zakorzenienie we wczesnych trynitarnych interpretacjach tajemnicy Chrystusa.

Jednak ten sam autor trójczłonową dialogową formułę chrzcielną datuje na połowę II wieku, wzmiankując (niestety, również bez

50 J. Gnilka, Teologia Nowego Testamentu, tłum. W. Szymona OP, Kraków 2002, s. 149.

51 J. Gnilka, Teologia Nowego Testamentu, dz. cyt., s. 145.

52 J. Gnilka, Paweł $z$ Tarsu. Apostoł $i$ świadek, przekł. W. Szymona OP, Kraków 2001, s. 379 . 
uchwytnego zakotwiczenia $\mathrm{w}$ przesłankach za tym przemawiających) o wbudowywaniu w nią starszych formuł chrzcielnych o charakterze chrystologicznym ${ }^{53}$.

Wśród polskich teologów należy zauważyć przychylność wobec umiarkowanego stanowiska argumentującego za możliwą interpolacją formuły chrzcielnej w zakończeniu Ewangelii św. Mateusza. Józef Kudasiewicz dał wyraz temu poglądowi ogólną wskazówką interpretacyjną: „należy odróżnić autentyczne, pierwotne słowa Pana (ipsissima verba Jesu) od elementów interpretacyjno-redakcyjnych" ${ }^{24}$. W wydanym w 1976 roku trzecim tomie monumentalnej Encyklopedii katolickiej lubelscy redaktorzy również odnieśli się do dyskusji dotyczącej formuły chrztu, przyjmując następujące stanowisko:

obecnie teologowie biblijni przyjmują, że formuła trynitarna ma charakter redakcyjny, stanowi odbicie praktyki Kościoła Pierwotnego. Jezus miał najprawdopodobniej zaznaczyć jedynie: „udzielajcie im chrztu w imię Moje” to znaczy: na mój rozkaz, z mojej mocy, by odróżnić swój chrzest od chrztu Jana Chrzciciela ${ }^{55}$.

Taką wykładnię prezentuje również biskup Kazimierz Romaniuk, biblista, w swojej monografii Sakramentologia biblijna:

znacznie częstsze są w Nowym Testamencie wzmianki o chrzcie „w imię Jezusa Chrystusa" lub w imię Pana Jezusa. [...]. Jego więc należało wspomnieć przede wszystkim podczas obrzędu przekazania życia neokatechumenowi (por. Dzieje Apostolskie 3, 15; 4, 12). Niewykluczone więc - to opinia większości dzisiejszych egzegetów - że formuła trynitarna jest tworem nieco późniejszym... ${ }^{56}$

53 Prawdopodobnie już od połowy II wieku, a wyraźniej już od III wieku, początkowo bardzo prosta trójczłonowa formuła, która zawierała tylko nakaz chrztu z Mt 28, 19 $\mathrm{w}$ formie pytania, została rozszerzona przede wszystkim w środkowej części wyznania chrystologicznego przez starsze formuły chrzcielne; dochodzi tutaj bowiem do głosu motyw specyficznie chrześcijański. Por. M. Fiedorowicz, Teologia ojców Kościota..., dz. cyt., s. 215.

54 J. Kudasiewicz, Jezus historii a Chrystus wiary, Lublin 1987, s. 106-107 (Jak Rozumieć Pismo Święte, 3).

55 Chrzest, [w:] Encyklopedia katolicka, t. III, red. F. Gryglewicz, R. Łukaszyk, Z. Sułowski, Lublin 1976, s. 354.

56 K. Romaniuk, Sakramentologia biblijna, Warszawa 1994, s. 19. 


\section{Czasy poapostolskie. Analiza źródeł}

Kościół II i III wieku, otoczony przez świat pogański i gnębiony prześladowaniami, poszukiwał swojej własnej tożsamości, co nie było łatwym zadaniem, gdyż nie istniały jeszcze wówczas rozwiązania prawno-teologiczne oraz praktyka kościelna, które określałaby normy postępowania w wielu kwestiach, także doktrynalnych.

Najstarszy tekst liturgiczny okresu wczesnego chrześcijaństwa, to jest Didache (I wiek), w rozdziale 7 szczegółowo opisuje trynitarną formułę chrztu.

1. Co do chrztu, to udzielajcie go w taki oto sposób: Powtórzywszy najpierw wszystko powyższe, chrzcijcie w imię Ojca i Syna, i Ducha Świętego w wodzie żywej.

2. Jeśli nie masz wody żywej, chrzcij w innej, jeśli nie możesz w zimnej, chrzcij w ciepłej.

3. Jeśli brak ci jednej i drugiej, polej głowę trzy razy wodą w imię Ojca i Syna, i Ducha Świętego ${ }^{57}$.

Urodzony w 100 roku Justyn Męczennik w Dialogu z Żydem Tryfonem nie powołuje się na trynitarną formułę chrztu:

Niektórzy spośród was stają się uczniami w imię Chrystusa i porzucając ścieżkę błędu, otrzymują dary, każdy według swych zasług, oświeceni przez imię tegoż Chrystusa. Otrzymują bowiem jeden ducha zrozumienia, inny rady, inny mocy, inny uzdrawiania, inny poznania, inny nauczania i inny bojaźni Bożej58.

Przywołany fragment tekstu bezpośrednio nawiązywał do Żydów, obeznanych z symbolem Ducha i rozumiejących porównanie Boga Jahwe do Ojca (Abba) oraz oczekujących mesjasza - Syna Bożego, jakkolwiek nie uznając go w osobie Jezusa Chrystusa. Tekst ten nie dowodzi, ale pozwala domniemywać słuszność poglądu reprezentowanego przez część teologów (np. Joachima Gnilkę, Michaela

57 Przekład polski w: Pierwsi świadkowie. Pisma Ojców Apostolskich, red. W. Zega, tłum. A. Świderkówna, przyp. M. Starowieyski, Kraków 2010, s. 33-44.

58 Tekst polski w: Antologia literatury patrystycznej, t. 1, przeł. i oprac. M. Michalski, Warszawa 1975, s. 99-109. 
Fiedorowicza, Hansa von Campenhausena, Antoniusa Brekelmansa, Aloisa Stenzela), że jeszcze w II wieku istniały obok siebie w Kościele dwa podstawowe ryty chrzcielne: praktykowany głównie w chrześcijańskich gminach żydowskich chrzest Chrystusowy („Żydzi wierzyli w jednego Boga i byli zaznajomieni z ideą Ducha św.") ${ }^{59}$ i chrzest z użyciem formuły trynitarnej, którą posługiwano się przepowiadając poganom. Szczególnie piękne w formie są twierdzenia Brekelmansa, który na pytanie, dlaczego obie wersje rytu chrzcielnego w czasie pierwszych dwóch wieków chrześcijaństwa nie są względem siebie konkurencyjne, nie stoją wobec siebie w sprzeczności ani w opozycji, odpowiada: „ponieważ mają na uwadze jedno i to samo dzieło Zbawienia"60.

W innym swoim dziele, Pierwszej Apologii (n. 61), św. Justyn dokładnie już opisał zarówno obrzęd chrztu z użyciem wezwania do Trójcy Świętej („oświecenia” - wyznania wiary w Trójjedynego Boga), jak i formułę chrztu - dwuczłonową w imię Jezusa Chrystusa ukrzyżowanego „pod Ponckim Piłatem” i w Ducha Świętego ${ }^{61}$. To wskazuje na rozciągnięcie w czasie liturgii chrztu, w której nie można było jeszcze wyodrębnić ścisłych podziałów.

Opis uroczystego nabożeństwa, w którym katechumen (a w imieniu dziecka, względnie osoby zrównanej do dziecka - jego rodzice lub opiekunowie i chrzestni ${ }^{62}$ ), wyrzekłszy się publicznie szatana ${ }^{63}$, głośno wyznawał wiarę katolicką, będąc trzykrotnie pytany o wiarę

59 A. Brekelmans, Wyznania wiary w pierwotnym Kościele. Powstanie i funkcje, tłum.

B. Skóra SDV, „Concilium. Międzynarodowy Przegląd Teologiczny” 1970 z. 1-5, s. $28-35$.

60 A. Brekelmans, Wyznania wiary w pierwotnym Kościele..., dz. cyt., s. 31.

${ }^{61}$ Justyn Męczennik, Apologia 1 [w:] Pierwsi apologeci greccy. Kwadratus, Arystydes $z$ Aten, Aryston z Pelli, Justyn Męczennik, Tacjan Syryjczyk, Milcjades, Apolinary $z$ Hierapolis, Teofil $z$ Antiochii, Hermiasz, przeł. L. Misiarczyk, J. Naumowicz, Kraków 2004, s. 207-270 (Biblioteka Ojców Kościoła, 24). Zob. również E. C. Whitaker, Documents of the baptismal liturgy, Minnesota 1970, s. 3. Więcej uwag tego samego autora na temat przeobrażeń wyznań chrzcielnych znajduje się w artykule: History of baptismal formuta, „The Journal of Ecclesial History” 16 (1965), s. 1-12.

62 P. Turner, Ages of initation. The first two Christian millenia, Collegeville MN 2000, s. $11,14,17$.

63 Na temat wyrzeczenia się zła i modlitwy z egzorcyzmem w obrzędzie chrzcielnym z perspektywy historycznej zob: The devil at baptism. Ritual, theology and drama, red. H. A. Kelly, New York-London 1995. Tradycja Apostolska Hipolita omówiona jest w rozdziale II. 5, s. 81-94. 
w Boga Ojca, Syna Bożego i Ducha Świętego, a po każdej odpowiedzi „wierzę" był zanurzany w wodzie, został zamieszczony w przypisywanej Hipolitowi i datowanej na ok. 215 rok Tradycji Apostolskiej. Taki obrzęd chrztu połączony z dialogowym wyznaniem wiary utrzymywał się do IV wieku na Wschodzie, a do VII na Zachodzie (IV Synod w Toledo w 633 roku zaaprobował jednokrotne zanurzenie w wodzie dla ważnego chrztu) i stopniowo był zastępowany formułą w trybie oznajmującym ${ }^{64}$. Następowały po nim kolejne sakramenty inicjacji chrześcijańskiej, to jest Eucharystia i bierzmowanie. Dopiero od IV wieku zauważa się rozdzielanie tych sakramentów w czasie ${ }^{65}$.

Kilkakrotnie na temat formuły chrztu - zawsze w formie trynitarnej - wypowiedział się Tertulian. W mowie Przeciw Prakseaszowi (n. 26) podkreślił związek pomiędzy trzykrotnym zanurzeniem $\mathrm{w}$ wodzie a wypowiedzeniem formuły trynitarnej nad przyjmującym chrzest. W homilii $O$ chrzcie (n. 13) cytuje fragment Ewangelii św. Mateusza 28, 19-20: „Ite, inquit, docete nationes tinguentes eas in nomine Patris et Filii et Spiritus Sancti. Huic legi collata definitio illa, Nisi quis renatus fuerit ex aqua et Spiritu Sancto non introibit in regno caelorum, obstrinxit fidem ad baptismi necessitatem. itaque omnes exinde credentes tinguebantur" $\left.{ }^{16}\right)$. Podobnie Orygenes w Komentarzu do Rzymian (5:8) zacytował trynitarne wezwanie chrzcielne, dodając, że tylko taki chrzest należy uznać za ważny ${ }^{67}$.

Trynitarnej formuły chrztu jako jedynie właściwej i poprawnej bardzo silnie bronił Cyprian z Kartaginy. W Liście 73 (n. 18) podkreślał, że nakaz misyjny wypowiedziany przez Chrystusa wobec apostołów zawierał nie tylko obowiązek głoszenia światu Dobrej Nowiny, ale również dokonywania chrztu w imię Ojca i Syna, i Ducha Świętego. Za czasów Cypriana była jeszcze praktykowana jednoczłonowa forma chrztu „w imię Jezusa” uznawana jako „stary zwyczaj

64 M. Fiedorowicz, Teologia ojców Kościoła..., dz. cyt., s. 217. Podobnie H. J. Carpenter, Creeds and baptismal rites in the first four centuries, "The Journal of Theological Studies" 44 (1943), s. 367-377.

65 P. Turner, Ages of initation..., dz. cyt., s. 8, 10.

66 Tertulian, De baptisimo, ed. B. Luiselli, Torino 1969 (Corpus Scriptorum Latinorum Paravianum, 32); wersja cyfrowa 2006, dostęp dzięki programowi Brill-online (2-6.12.2013).

67 Szerzej na temat liturgii chrztu w pierwszych wiekach chrześcijaństwa: A. Stenzel, Il battesimo. Genesi e evoluzione della liturgia battesimale, Alba 1962, s. 63-89, 129-146. 
apostołów", ale właśnie ona stała się symbolem wykorzystywanym przez pojawiające się ruchy heretyckie. Cyprian przyjął przeciwne do papieża Stefana I stanowisko wobec uznania ważności chrztu dokonanego przez schizmatyków i heretyków. Historia tej dyskusji znajduje się w Listach biskupa z Kartaginy (Listy 69-74 oraz List 75, adresowany do Cypriana przez Firmiriana).

Argumentacja Cypriana i Stefana I opierała się na tym samym: doświadczeniu communio - jedności Kościoła, z tym że Cyprian jako klasyczny pragmatyk obawiał się, czy chrzest heretyków udzielony „w imię Jezusa" nie spowoduje zamętu i kolejnych kontrowersji teologicznych. Ten afrykański biskup w arystotelesowski sposób (przejęty później przez św. Tomasza) rozumiał znaczenie prawdziwości rzeczy: „veritas est id, quod est” lub też „veritas est adequatio rei et intellectus" i domniemywał zgodę słów, gestów i znaków z intencją wewnętrzną szafarza oraz przyjmującego chrzest podczas sprawowania tego sakramentu. Formuły inne niż trynitarne nie dawały w jego przekonaniu gwarancji zaistnienia prawdziwej łaski w człowieku. Abraham van de Beek opublikował w 2009 roku artykuł Heretical baptism in debate ${ }^{68}$, w którym wypunktował argumenty zwolenników i przeciwników powtórnego chrztu heretyków i odstępców w III wieku. Holenderski teolog cytuje interesujący anonimowy dokument: De rebaptismate, datowany na rok 250, popierający punkt widzenia Rzymu. W dziele tym wskazuje się, że skoro jacyś ludzie zostali ochrzczeni poza Kościołem („extra Ecclesia”) „w imię Jezusa Chrystusa", to powinno się dokończyć ich ryt chrzcielny poprzez rozlanie na nich za pośrednictwem biskupa Ducha Świętego, zgodnie z praktyką wskazaną w Dziejach Apostolskich ${ }^{69}$.

Synod w Arles (w 314 roku) przyjął w duchu epikei i miłosierdzia decyzję o włączaniu do Kościoła schizmatyków, a chrzest heretyków - o ile odbywał się zgodnie $\mathrm{z}$ wiarą Kościoła i intencją czynienia tego, czego chce Kościół - również uważano za ważny. Powtórny chrzest nie był wymagany (papież Stefan I zabronił pod karą ekskomuniki chrzcić na nowo heretyków), ale od byłych odstępców żądano publicznego, trynitarnego wyznania wiary. Czasem

68 A. van de Beek, Heretical baptism in debate, „In die Skriftlig” 2009 nr 43 (3), s. $537-561$.

69 A. van de Beek, Heretical baptism..., dz. cyt., s. 541-542. 
tylko praktykowano chrzest warunkowy, gdy istniała wątpliwość co do ważności chrztu (np. gdy szafarz powiedział: „chrzczę cię w imię Trójcy Świętej"70). W debacie św. Augustyna z donatystami Listy Cypriana odgrywały ogromną rolę. Augustyn rozwinął bowiem myśl teologiczną Cypriana odnośnie do ważności lub nieważności chrztu heretyków. Mając na uwadze doświadczenie Boga przez człowieka, przyjął inne stanowisko niż biskup z Kartaginy, niezmiernie ściśle i formalnie zachowując jednak polecenia Synodu z Arles o konieczności złożenia wyznania wiary w Trójjedynego Boga przez heretyków ochrzczonych „w imię Jezusa”.

\section{Starożytne wyznania wiary a trynitarna formuła chrztu}

Ustanie prześladowań ułatwiło chrześcijanom prowadzenie działalności także w wymiarze organizowania synodów i soborów. Zachowane dokumenty wskazują na szerokie zainteresowanie biskupów Kościoła licznymi kwestiami istotnymi dla ówczesnych wspólnot lokalnych: sprawami dyscyplinarnymi, błędami teologicznymi, odstępstwami od doktryny. Formalnym spotkaniom hierarchów towarzyszyła epistolarna wymiana myśli teologicznej, którą w treści i celu możemy porównać do współczesnej dyskusji naukowej.

Poczynając od przełomu związanego z edyktem Konstantyna, Kościół mógł liczyć na nadawanie przez cesarzy dekretom soborowym rangi obowiązującego prawa. Równocześnie, to jest w IV i V wieku, obserwuje się wzrost aktywności ruchów heretyckich (w szczególności arian) negujących trynitarną naukę Kościoła. W spór z heretykami zaangażowani byli nie tylko pasterze Kościoła. W związku z rozpoczętą w IV wieku praktyką nadawania Kościołowi przywilejów przez chrześcijańskich władców, również autorytety państwowe były żywo zainteresowane jasnym ustaleniem, kogo mają uważać za prawowitego biskupa. Jedność i prawomyślność doktrynalną - weryfikowaną odniesieniem do credo - uzyskiwano nie tylko w wyniku kolegialnych ustaleń biskupów w ramach ich aktywności legislacyjnej

70 Przykład pochodzi z hasła Baptism, [w:] Catholic Encyclopedia. An international work of reference on the constitution, doctrine, discipline, and history of the Catholic Church, ed. E. A. Pace et al., vol. 2, www.newadwent.org/cathen/00001a.htm (10.08.2014). 
na synodach i soborach, ale również w sposób praktyczny wymuszano ją wiążącymi poddanych decyzjami chrześcijańskich cesarzy ${ }^{71}$.

Teologowie tego okresu nie wypracowali jeszcze jednoznacznego, obowiązującego w całym Kościele tekstu wyznania wiary. Poszczególne Kościoły lokalne charakteryzowały się dużą autonomią, zwłaszcza w zakresie stosowanych obrzędów i zwyczajów liturgicznych. W IV i V wieku spisano wiele prywatnych wyznań wiary układanych przez poszczególnych ludzi Kościoła, głównie dla podkreślenia ich ortodoksyjności lub poprawności głoszonych przez nich tez. Takie wyznania wiary, powstałe $\mathrm{w}$ wyniku sporów doktrynalnych lub publicznych dyskusji, były czasem - po późniejszej redakcji i ustaleniach w zakresie terminologii - akceptowane pisemnie przez biskupów i podawane jako obowiązujące na terenach danych im pod duszpasterską pieczę. Źródła tych wyznań wiary, zwanych „symbolami prywatnymi”, pochodziły z lokalnych obrzędów chrzcielnych, gdzie w sposób symbiotyczny, zasadniczo nierozłączny wypowiadane credo przeplatało się z formą chrztu i jego liturgią. Związek wyznania wiary (inaczej: reguły, symbolu wiary) z formułą chrztu w pierwszych wiekach chrześcijaństwa był bowiem bardzo ścisły. Wystarczy przypomnieć, że do pierwszej połowy IV wieku cały dialogowy obrzęd chrztu łącznie z jego formułą oznaczał równocześnie wypowiedzenie credo. Fiedorowicz podaje, że już od około 190 roku trójczłonowy symbol chrzcielny (wyznanie wiary) mógł pełnić funkcję sprawdzianu ortodoksji ${ }^{72}$, gdyż w tym czasie w Kościele panowało przekonanie (rozpowszechnione następnie w IV wieku), że reguła wiary pochodzi od apostołów, którzy przed rozpoczęciem misji ewangelizacji wspólnie ustalili jej brzmienie.

Dzięki praktyce chrzcielnej stosowanej we wszystkich niemal Kościołach lokalnych formuła trynitarna już w IV wieku była uznana za zwyczaj „starożytny”73. W tym też czasie zarówno wschodnie, jak i zachodnie wyznania wiary zawierają trynitarną formułę chrzcielną jako łączący je wspólny mianownik. Słuszny wydaje się pogląd Michaela Fiedorowicza, że stosowanie tak jednolitej formy jeszcze przed

\footnotetext{
71 Por. M. Fiedorowicz, Teologia ojców Kościoła..., dz. cyt., s. 225.

72 M. Fiedorowicz, Teologia ojców Kościoła..., dz. cyt., s. 223. Autor powołuje się na Rufina z Akwilei.

73 Fiedorowicz wskazuje również, że trynitarna formuła chrztu powstała przed ogłoszeniem poglądów przez Ariusza. Por. M. Fiedorowicz, Teologia Ojców Kościoła..., dz. cyt., s. 258.
} 
ukończeniem dogmatycznego wyjaśnienia doktryny Trójcy wskazywało na silne zakorzenienie w powszechnej świadomości Kościoła trynitarnego charakteru wczesnochrześcijańskiej wiary i dlatego ta właśnie formuła chrztu jako „argument z praktyki wiary Kościoła” stanowiła dużą siłę dowodową ${ }^{74}$. Ścisły związek reguły wiary z formułą chrztu widać dość jasno u Bazylego Wielkiego, który w jednym ze swych listów napisał: „winniśmy tak chrzest przyjmować jak nas pouczono $^{75}$, wierzyć, jak nas ochrzczono"76.

Znaczenie i funkcja całego obrzędu chrzcielnego i liturgii chrzcielnej miała na celu przypomnienie, wskazanie oraz nauczanie o poprawności doktrynalnej wiary i umocnienie chrześcijańskiej tożsamości. Wspominany już Leo F. Miller w swojej publikacji z 1925 roku77 podzielił źródła pisemne traktujące o formule chrztu na trzy części, wyodrębniając te, w których mowa jest o „chrzcie w imię Jezusa”, te, które w swojej treści wezwania trynitarnego zgodne są z greckim tekstem Ewangelii św. Mateusza, oraz te, które wspominają o chrzcie w formie trynitarnej, lecz jej nie cytują. Autor zauważył, że ci sami autorzy (ojcowie Kościoła, papieże) różnie pisali o chrzcie w zależności od tego, jaki był temat przewodni ich dzieła. Najmniej liczna była grupa druga. Najczęściej pisano o trynitarnej, a nie chrystologicznej formule chrztu, jednakże nie cytując jej samej. Próbując wypośrodkować stanowisko, Miller przede wszystkim kładł nacisk na brak logicznej sprzeczności między wczesnochrześcijańskim chrztem w imię Jezusa praktykowanym w Kościołach patriarchalnych będących w łączności z Rzymem ${ }^{78}$ a trynitarnym wyznaniem wiary Kościoła. Ponieważ kształtowały się dopiero jednolity obrzęd chrztu i jednolita liturgia Kościoła, zaś sam wspomniany sakrament poprzedzony był głośnym wyznaniem wiary, nie powinna dziwić liczba różnych praktyk w młodym Kościele, niepokojonym krwawymi prześladowaniami.

74 M. Fiedorowicz, Teologia Ojców Kościoła..., dz. cyt., s. 220, 258-259.

75 Chodzi to o tzw. traditio symboli, które biskup na 3 tygodnie przed chrztem w sposób uroczysty powierzał katechumenowi i z którego go później „odpytywano” (redditio). Więcej o tej dydaktyce katechetycznej IV wieku zob. J. N. D. Kelly, Early Christian creeds, London-New York 1972, s. 49-52.

76 Bazyli Wielki, Listy 125, 3, wybór, przekł. z jęz. grec., wstęp, przypisy i indeksy W. Krzyżaniak, Warszawa 1972, s. 156-157.

77 L. F. Miller, The formula of baptism..., dz. cyt., szczególnie s. 517-528.

78 Autor przypomniał, że już pod koniec czasu apostołów w Kościele pojawiły się herezje; w takich wspólnotach chrzczono przy użyciu różnych formul, w tym także formuły chrystologicznej i quasi-trynitarnej. 
Z perspektywy dwudziestu wieków, bazując na strzępkach zachowanych źródeł, Miller zauważył, że możliwa jest bardzo zróżnicowana interpretacja zagadnienia formuły chrztu. W swoim artykule, będącym próbą złagodzenia tonu dyskusji, zwracał on przede wszystkim uwagę na ścisłą relację i bardzo krótki dystans czasowy pomiędzy wyznaniem wiary przyjmującego chrzest a samym aktem chrztu.

Uzupełniając tę myśl, Michael Fiedorowicz wskazywał, iż w Kościele, obok funkcji dogmatycznej, treść credo służyła również celom katechezy oraz była swoistym „miernikiem prawdy” czy też kryterium pomocnym w osądzeniu, która nauka jest prawdziwa, a która fałszywa, i że dopiero od czasu sporu z arianami w literaturze Kościoła łacińskiego symbol wiary zaczął oznaczać wyłącznie formułę wy-

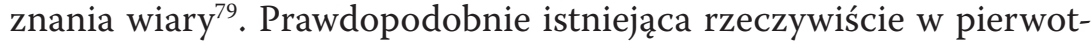
nym Kościele różna praxis chrzcielna - echo odrębności kulturowej i filozoficznej pierwszych starożytnych Kościołów - która łączyła w sobie zarówno złożenie wyznania wiary w Trójjedynego Boga, jak i formułę chrzcielną „w imię Jezusa”, wobec nasilających się w IV i V stuleciu herezji antytrynitarnych, zaczęła zaciemniać obraz rzeczywistości „wiary prawdziwie istniejącej”

$\mathrm{Z}$ zachowanych listów papieży oraz ojców Kościoła pisanych w okresie kontrowersji trynitarno-chrystologicznej można wywnioskować, że właśnie uznanie trynitarnej formuły chrztu jako jedynej akceptowalnej wyznaczyło prosty i zarazem praktyczny sposób określenia, jaki chrzest heretyków można uznać za „pełny” i ważny, a jaki za niezaistniały, a zatem wymagający prawdziwego znaku łaski (powtórnego chrztu) ${ }^{81}$. Ilustracją niech będzie Synod w Arles z 314 roku, na którym obradujący biskupi podjęli w kanonie IX decyzję, iż heretyk starający się o przyjęcie do Kościoła musi powiedzieć, w jakiej formie został ochrzczony: czy w trynitarnej, czy też w innej. Trójczłonowa forma chrztu oraz wyznanie wiary w Trójcę powodowały, iż jego chrzest uważano za ważny ${ }^{82}$.

\footnotetext{
79 M. Fiedorowicz, Teologia ojców Kościoła..., dz. cyt., s. 209.

80 „Wiara opiera się na rzeczach prawdziwie istniejących". Ireneusz z Lyonu, Wykład nauki apostolskiej, epid. 99-100, tłum. i oprac. W. Myszor, Kraków 1997, s. 24 (Źródła Myśli Teologicznej, 7).

81 Por. Dokumenty synodów od 50 do 381 r., red. A. Baron, H. Pietras, Kraków 2006 (Źródła Myśli Teologicznej, 37; Synody i Kolekcje Praw, 1).

82 Dokumenty synodów od 50 do 381 r., dz. cyt., s. 70.
} 
Dodatkowo osadzenie trynitarnej formuły chrztu w tekście Mateuszowej Ewangelii ${ }^{83}$ oraz w pismach żyjących wcześniej autorytetów (wyznań prywatnych, homilii oraz listów), a także jasność i przejrzystość tej zasady spowodowały, że pomimo trwających jeszcze w V wieku dysput formuła zyskała w Kościele powszechną akceptację. W tej optyce, jak się wydaje, należy również interpretować i szukać wyjaśnienia silnego przyjęcia i podkreślania trynitarnej formuły chrztu jako jedynej poprawnej w Kościele oraz szybkiego „wyciszenia” formuły chrztu „w imię Jezusa” w czasach poapostolskich.

\section{Podsumowanie}

Metodologiczne problemy z naświetleniem kwestii formuły chrztu i jej ewolucji w pierwszych wiekach chrześcijaństwa są bardzo duże. Badacze dysponują niewielką ilością danych historiograficznych, a to rodzi ryzyko bezkrytycznego korzystania z wyizolowanych źródeł, "słuchania solistów, a nie chóru" (Jaroslav Pelikan) i prowadzi do powstania skrajnych poglądów, które siłą rzeczy upraszczają problem. Należy wziąć pod uwagę niejednorodność źródeł, z których trzeba - nie bez trudu - wydestylować wpływy, zapożyczenia i naleciałości z czasów późniejszych oraz mieć na uwadze, że różne ocalałe manuskrypty wespół z wczesnymi cytatami patrystycznymi mogą tworzyć różne wersje tego samego tekstu. Studia nad pismami ojców Kościoła także należy poddać krytycznej ocenie. (Dość przypomnieć, że duże partie dzieł Orygenesa zachowały się wyłącznie w tłumaczeniu łacińskim Rufina, co wymusza pewien sceptycyzm w przyjmowaniu tez tego ojca Kościoła). Trzeba również pamiętać, że w Kościele przednicejskim doktrynalny, egzegetyczny i liturgiczny materiał niejednorodnego rodzaju gromadził się i ulegał kompilacji w jedną całość, bez ścisłego rozróżnienia. Stąd wydaje się, że konkludując rozważania nad formułą chrztu w okresie wczesnochrześcijańskim, winno się przyjąć za Jaroslavem Pelikanem następujące stanowisko: „Być może jedynym sposobem jest zaakceptowanie istniejącego

83 Bazyli Wielki swoje argumenty „za” opiera na powołaniu się bezpośrednio na Ewangelię: „skoro chrzest został nam udzielony przez Zbawiciela w imię Ojca i Syna i Ducha Św. [...]". Bazyli Wielki, Listy 159, 2, dz. cyt., s. 174. 
«półcienia» i poszukiwanie granic, które można by zarysować w jego obrębie, nie ignorując dowodów"84.

Odnośnie do prezentowanego zagadnienia (wypowiadanej formuły chrztu na początku istnienia chrześcijaństwa) wykazano, iż na przestrzeni ponad 200 lat ścierały się ze sobą dwa stanowiska.

W protestanckiej myśli teologicznej hipoteza o możliwej interpolacji formuły trynitarnej zawartej w Ewangelii według św. Mateusza (Mt 28, 19-20) została w XVIII wieku w sposób adekwatny do nowożytnej nauki podjęta przez Niemca, Abrahama Tellera, podczas dokonywania redakcji i opracowania pośmiertnego dzieła angielskiego teologa Thomasa Burneta De Fide et Officiis Christianorum. Podobnie uważał szkocki tłumacz, Robert Young, gdy w 1862 roku wydawał swoją Young's literal translation Bible. Ten należący do prezbiterian biblista zdecydował się odróżnić frazę „w imię Ojca i Syna, i Ducha Świętego" w Ewangelii św. Mateusza (Mt 28, 19-20), wyodrębniając ją kursywą. We Francji protestancki teolog i historyk wczesnego chrześcijaństwa Edmond de Pressencé ${ }^{85}$ opowiedział się za istnieniem w Kościele pierwotnym jednoosobowej formuły chrztu w imię Jezusa, argumentując to faktem, że w Nowym Testamencie brakuje przykładów kompletnych takich formuł.

Impulsem do dyskusji i nowych badań nad zagadnieniem formuły chrztu u pierwszych chrześcijan stał się artykuł Fredericka Conybeare'a (1901), który dzięki analizie dzieł Euzebiusza z Cezarei i Orygenesa doszedł do wniosku, że fragment Mt 28, 19-20 pierwotnie brzmiał chrystocentrycznie: „Idźcie i nauczajcie inne narody, chrzcząc je w Moje imię". Orędownikami słuszności hipotezy dotyczącej „krótkiej formy” chrzcielnej w Mateuszowej Ewangelii byli liczący się badacze Pisma Świętego, wywodzący się z różnych wyznań chrześcijańskich: Hans Kosmala (dyrektor Szwedzkiego Instytutu Teologicznego w Jeruzalem w latach 1951-1971), zmarły w 2007 roku brytyjski profesor H. Benedict Green CR (ceniony znawca i komentator Ewangelii św. Mateusza), czy Everett Ferguson, współczesny amerykański historyk Kościoła i filozof religii.

\footnotetext{
84 J. Pelikan, Powstanie wspólnej tradycji (100-600), tłum. M. Höffner, red. J. Żelazny, Kraków 2008, s. 128.

85 E. de Pressencé, Early years..., dz. cyt. Wydanie francuskie pochodzi z 1868 roku.
} 
Bezpośredniej polemiki z tezami Conybeare'a dokonał Franklin Henry Chase w 1905 roku. Na łamach prestiżowego "Journal of Theological Studies" (wydawanego przez uniwersytet w Oxfordzie) bronił integralności i jednorodności spornej perykopy Nowego Testamentu, uznając, że wnioski Conybeare'a opierają się na wąskiej interpretacji wyizolowanych źródeł bez uwzględnienia innych pism patrystycznych tego okresu, trynitarnej tradycji chrzcielnej kilkuwiekowego wówczas Kościoła oraz kontekstu historycznego w aktywności pisarskiej Euzebiusza. Hipotezę Conybeare’a podważał również Bernard H. Cuneo. Katolicki teolog i historyk Kościoła w 1923 roku opowiadał się za tezą, że Euzebiusz z Cezarei nie dokonywał wiernej cytacji Ewangelii, lecz używał peryfraz i omówień w celach stylistycznych. Stąd badacz nie przychylał się do tezy o występowaniu interpolacji w perykopie 28, 19-20 Ewangelii św. Mateusza.

Skupiona przede wszystkim na działaniach defensywnych doktryna katolicka XIX wieku nie poświęcała swojej uwagi temu zagadnieniu inaczej niż przez pryzmat historyczny (kontrowersje $\mathrm{z}$ arianami w IV i V wieku). Kościół katolicki bardzo czujnie stał na straży poprawności doktrynalnej i prawomyślności, utrzymując w kwestii zagadnienia rozbieżności między formułą trynitarną zawartą w Ewangelii a brakiem jej występowania w Dziejach Apostolskich autorytatywne stanowisko św. Tomasza z Akwinu, że apostołowie otrzymali od Chrystusa dyspensę od używania formuły chrystologicznej $^{86}$. Nie umniejszając wielkości akwitańskiemu mistrzowi scholastyki, trzeba powiedzieć, że jego interpretacja nie znajduje oparcia w żadnych źródłach. Być może autorytet Akwinaty spowodował, że przez długi czas w Kościele katolickim nie podważano tego twierdzenia i nie dopuszczano do polemiki $\mathrm{z}$ anachronicznym poglądem uczonego. Jednakże po słynnej publikacji F. Conybeare’a w słowniku Dictionnaire d'archeologie chrétienne et de liturgie z 1910 roku pod redakcją Fernanda Cabrola, francuskiego historyka Kościoła i liturgisty, w artykule omawiającym hasło "chrzest" wiele miejsca poświęcono polemice z poglądem, że w Kościele pierwotnym praktykowany był chrzest w imię Jezusa. Dom de Puniet, autor tego hasła, bronił pierwotności trynitarnej formuły chrztu argumentem braku

86 Tomasz z Akwinu, Summa theologiae III, q. 66, a. 6, ad 1, www.corpusthomisticum. org/iopera.html\#OM (9.12.2014). 
wyodrębnienia formuły chrztu i wyznania wiary w pierwotnym Kościele, wskazując, że wyznania wiary zastępowały formułę tego sakramentu. Swoje racje wzmacniał pośrednimi dowodami z Dziejów Apostolskich (Dz 19, 1-7). Podobnie stwierdził w 1950 roku Joseph Crehan, który podawał w wątpliwość zasadność rozumienia fragmentów o "chrzcie w imię Jezusa” w Dziejach Apostolskich jako dowodów na istnienie jednoosobowej formuły chrztu, argumentując, że brak jest w Dziejach Apostolskich sformułowanych expressis verbis inwokacji chrzcielnych - w przeciwieństwie do zakończenia Ewangelii św. Mateusza, gdzie taka formuła została zamieszczona.

Przypomnieć też należy, że równocześnie od lat 20. XX wieku wśród katolickich teologów i historyków Kościoła istniał pogląd (Millera i innych) uznający za możliwą późniejszą redakcję Mt 28, 1920 i wskazujący na występowanie w tekstach źródłowych pierwszych czterech wieków chrześcijaństwa różnych cytatów i omówień formuły chrztu. Ci badacze skupili się na analizie momentu przejścia formuły chrztu z chrystologicznej w trynitarną w kontekście symbiotycznej relacji pierwszych credo (chrzcielnych wyznań wiary) z ceremonią szafowania sakramentu chrztu. Taka interpretacja widoczna jest również w czasach trwania Soboru Watykańskiego II (Antonius Brekelmans, Edward Charles Whitaker) $^{87}$.

Interesujący pogląd na temat interpretacji frazy „w imię Jezusa” występującej w Dziejach Apostolskich zaprezentował w 1971 roku ewangelicki uczony Hans von Campenhausen, który w artykule Taufe auf den Name Jesu? przekonywał, że słowa „w imię Jezusa” należy rozumieć jako nazwę własną chrześcijańskiego chrztu („chrzest Chrystusowy") w odróżnieniu od pogańskich inicjacji z użyciem wody czy też chrztu udzielanego przez Jana Chrzciciela. Częściowo logikę wywodów Campenhausena przyjęli inni współcześni teologowie: związany z Uniwersytetem w Yale liturgista Aidan Kavanagh czy wybitny amerykański ekumenista i dogmatyk Robert W. Jenson ${ }^{88}$.

Joachim Gnilka prezentował pogląd, iż chrześcijaństwo pierwszego wieku nie znało jeszcze trynitarnej formuły chrztu, lecz używało

\footnotetext{
87 Kolejne wydania książki E. C. Whitakera, Documents of the baptismal liturgy, dz. cyt. (również wyd. I, London 1960); A. Brekelmans, Wyznania wiary w pierwotnym Kościele...., dz. cyt.

88 R. W. Jenson, The Triune God..., dz. cyt.; A. Kavanagh, The shape of baptism..., dz. cyt.
} 
wezwania Chrystusa ${ }^{89}$. Podobnie w 1970 roku na łamach „Concillium” wypowiedział się holenderski teolog Antonius Brekelmans. Ostrożniej budował swe wnioski Michael Fiedorowicz ${ }^{90}$, jednak i on przyjął, że do połowy II, a nawet w III wieku istniały obok siebie równoległe formuły chrzcielne: trynitarna i chrystocentryczna.

Ignorowanie wyników badań językowych nad perykopą Mt 28, 1920 jest naukowo bezzasadne. Należy przyjąć, że trynitarna formuła chrztu jest rzeczywiście interpolacją tego fragmentu Ewangelii ${ }^{91}$. Rację mają zatem ci uczeni, którzy twierdzą, że najbliższa prawdzie historycznej jest interpretacja literalna wyrażeń „chrzest w imię (Pana) Jezusa" w Dziejach Apostolskich. Przez wieki w przekazywanej sobie tradycji istniało przekonanie o prawdziwości faktu, iż apostołowie rzeczywiście udzielali chrztu $\mathrm{w}$ imię Jezusa. Praktyka ta nie została nigdy zakwestionowana w Kościele czasów patrystycznych, choć z zachowanych pism z IV wieku wynika, iż coraz silniej pojawiało się w świadomości Kościoła przekonanie o „jednorazowości” czy też „wyłączności” takiej formuły chrztu dla apostołów i tych uczniów Chrystusa, którzy mieli z Nim bezpośredni kontakt. Podczas poszukiwań bibliograficznych czynionych na potrzeby tej publikacji pod hasłem "chrzest w imię Jezusa" znaleziono wiele pozycji podających w wątpliwość oryginalność formuły chrztu wyrażonej w Mt 28, 1920; jednakże ani bibliści, ani historycy Kościoła nie wysuwali takich hipotez pod adresem Dz 2, 38; 8, 16; 10, 48 czy 19, 5. Biorąc pod uwagę centralną postać Chrystusa w teologii Nowego Testamentu (co widoczne jest w szczególności u św. Pawła), budowanie tożsamości wiary na Jego osobie oraz kontekst historyczno-kulturowy (tygiel kosmopolityczny) Cesarstwa Rzymskiego I wieku, można uznać, że formuła chrztu „w imię Jezusa”, czy też „w imię Pana Jezusa” była pierwszą i najstarszą w Kościele. Obecność licznych odwołań w Dziejach Apostolskich do relacji Boga Ojca - Syna Odkupiciela - Ducha Świętego pozwala sądzić, że skoro przyjęcie chrztu poprzedzało wyznanie wiary (najprawdopodobniej w podniosłej formie dialogowej, jeszcze przed Didache) to sama formuła aktu chrztu mogła zawierać się w słowach „w imię Jezusa”. Stanowczo jednak należy podkreślić, że

89 J. Gnilka, Teologia Nowego Testamentu, dz. cyt.; J. Gnilka, Paweł z Tarsu, dz. cyt.

90 M. Fiedorowicz, Teologia ojców Kościoła..., dz. cyt.

${ }^{91}$ J. Kudasiewicz, Jezus historii a Chrystus wiary, dz. cyt.; K. Romaniuk, Sakramentologia biblijna, dz. cyt. 
wymienianie nad przyjmującym chrzest jedynie imienia Chrystusa oznaczało $\mathrm{w}$ istocie akceptację całej judeochrześcijańskiej tradycji tajemnicy Trójcy, jakkolwiek jej ostateczny kształt w postaci dogmatu wciąż jeszcze tworzył się w Kościele. Ostatecznie, chociaż kusząca, nie wydaje się słuszna hipoteza niektórych badaczy (Brekelmansa i innych ${ }^{92}$ ), że żydowskich konwertytów obeznanych z ideą Boga Ojca i Ducha chrzczono w imię Jezusa, a pogan w imię Trójcy Świętej. Przeczą temu te fragmenty Dzieł Apostolskich, które wspominają o apostołach udzielających chrztu Żydom, a także Korneliuszowi (Dz 10, 48) oraz dworzaninowi etiopskiemu (Dz 8, 37).

Kościół katakumb nie wymagał do ważności chrztu jakiejś specjalnej ceremonii, czasu ani miejsca, choć kształtujące się normy liturgiczne opisywały i zalecały uroczysty i publiczny charakter tego sakramentu, który przyjmowano - jak wskazują źródła - z dużą świadomością. Starożytna liturgia i symbolika chrzcielna oraz interrogacyjny charakter obrzędu chrztu w naturalny sposób wplatały się w trynitarne credo nawracającego się na chrześcijaństwo. Za bardzo starą praktyką trynitarnej formuły chrztu przemawia argument z wczesnej tradycji liturgicznej Kościoła (Didache 7.1) oraz „odwołanie się do [praktyki - przyp. aut.] Kościołów założonych przez apostołów jako poręczycieli apostolskiej sukcesji” ${ }^{\prime 2}$.

Wypracowywana praktyka liturgiczna Kościoła oraz jej ścisły, wręcz symbiotyczny związek z doktryną wczesnochrześcijańską mogły skutkować najpierw glosą (pisemną notą na marginesie, przepisywaną w takiej formie) a później utrwaleniem tej glosy. Kolejnym krokiem stało się przeredagowanie formuły chrztu zawartego w nakazie misyjnym Chrystusa. Otwarte pozostaje pytanie, jak wczesny był to zabieg.

Niektórzy wspomniani w niniejszej publikacji badacze (np. Frederick Conybeare) szacowali pojawienie się formy trynitarnej chrztu w tekście Ewangelii św. Mateusza na drugą połowę II wieku (od ok. 140 roku n.e.). Adwersarze tego poglądu nie zgadzali się całkowicie z taką interpretacją, wszelako nie zaproponowali innej, konkurencyjnej wykładni. Współcześni teologowie przyjmują, że zmiana redakcyjna w Mateuszowej Ewangelii rzeczywiście mogła mieć wówczas

\footnotetext{
92 A. Brekelmans, Wyznania wiary w pierwotnym Kościele..., dz. cyt.

93 J. Pelikan, Powstanie wspólnej tradycji..., dz. cyt., s. 123.
} 
miejsce, gdyż w pismach kanonicznych (jak i apokryfach) ${ }^{94}$ datowanych na czas między II a III wiekiem obserwowana jest powtarzająca się cytacja nakazu misyjnego Chrystusa: „idźcie i nauczajcie wszystkie narody, udzielając im chrztu w imię Ojca i Syna, i Ducha Świętego". Źródłem tych cytatów - jak piszą sami autorzy (np. Tertulian) - jest Ewangelia. Chrzcielne formuły i wyznania wiary mające trójczłonową strukturę trynitarną nie pojawiły się w liturgii Kościoła nagle, lecz były zakorzenione we wczesnych trynitarnych interpretacjach Pisma Świętego. Dlatego też początkowa glosa, a następnie interpolacja pierwotnego fragmentu Ewangelii rozpowszechniła się tak łatwo i stosunkowo szybko.

W obrębie basenu Morza Śródziemnego, północnej Afryki i Półwyspu Arabskiego czas II i III wieku jest - na przekór prześladowaniom - okresem wielkich sukcesów misyjnych. Równocześnie od końca I wieku w głównym nurcie ortodoksyjnym pojawiły się poważne pęknięcia doktrynalne. Już w Dziejach Apostolskich jest mowa o próbach zawłaszczenia sobie „atrakcyjności” chrześcijaństwa przez przywódców starożytnych sekt i ruchów religijnych. Trynitarne wyznanie wiary w formie symbolu prywatnego - wypowiadane przez przyjmującego chrzest bezpośrednio przed zanurzeniem go w wodzie chrzcielnej - stało się również świadectwem i sprawdzianem ortodoksji. Jednym z „sukcesów" rozprzestrzenienia się formuły trynitarnej chrztu była pojawiająca się konieczność ustalenia w młodym Kościele, kto jest heretykiem, a kto nie. Wiara w dogmat o Trójjedynym Bogu okazała się skutecznym, a równocześnie prostym narzędziem weryfikacji wierności Ewangelii.

Przechodzenie z formuły chrystologicznej na trynitarną odbywało się prawdopodobnie w sposób ewolucyjny, wraz z rozwojem doktryny Kościoła i wyodrębnianiem się od niej norm liturgicznych oraz dyscyplinarnych. W zależności od parametrów geopolitycznych, kulturowych (monoteizm Izraelitów contra politeizm imperium grecko-rzymskiego) oraz zagrożeń płynących z nurtów heretyckich, formuła chrztu „w imię Jezusa” przetrwała krócej lub dłużej w praktyce poszczególnych Kościołów patriarchalnych. Wiadomo, że w czasie kontrowersji z arianami egzystowała już jako mniej powszechna,

94 Dzieje Ksantypy i Polikseny 21, [w:] Apostołowie, cz. 2, Bartłomiej, Filip, Jakub Mniejszy, Jakub Większy, Judasz, Maciej, Mateusz, Szymon i Juda Tadeusz ewangeliści, uczniowie pańscy, pod red. M. Starowieyskiego, współpr. K. Bardski, Kraków 2007 (Apokryfy Nowego Testamentu, 2). 
choć szczyciła się „starożytnym” (w oczach ówczesnych) rodowodem. Gdyby jednak przyjąć jakąś datę graniczną, można uznać, że impulsem do powszechnego stosowania formuły trynitarnej chrztu był Sobór Nicejski (w 325 roku). Tekst formuły chrztu od początku miał przedstawiać jak najwięcej z wiary i jej treści. Inwokacja trynitarna $\mathrm{w}$ formule chrztu spełniała tę rolę, szczególnie wobec nasilonych w IV i kontynuowanych w V wieku kontrowersji ariańskich. Dlatego też drugą połowę IV wieku należy uznać za pewien czas schyłkowy w koegzystencji formuł chrztu chrystocentrycznej i trynitarnej oraz uznawaniu ich za równoważne. Jeśli po 381 roku (po soborze konstantynopolitańskim) pojawiały się świadectwa chrztu „w imię Jezusa”, to miały one miejsce szczególnie w środowiskach endemicznych lub wspólnotach nękanych przez herezje antytrynitarne i były często przywoływane jako element dyskusji nad ważnością takiego chrztu.

Na podstawie zebranych i przedstawionych $\mathrm{w}$ tej publikacji danych można podać przybliżony czas przejścia formuły chrzcielnej z chrystologicznej $\mathrm{w}$ trynitarną. Wydaje się, że wymienianie nad kandydatem do chrztu z osobna imienia Ojca, Syna i Ducha Świętego ugruntowało się w Kościele powszechnym w czasie poaugustiańskim, gdy następował upadek Cesarstwa zachodniorzymskiego. Łączący elementy doktrynalne z liturgicznymi dialogowy obrzęd chrztu, jaki opisuje Hipolit w Tradycji Apostolskiej, utrzymał się na Wschodzie do IV wieku, a na Zachodzie do VII wieku. Dla poprawności doktryny taki chrzest z potrójnym zanurzeniem lub polaniem mógł odbyć się zarówno z użyciem formuły trynitarnej, jak i chrystologicznej. Praktyka jednorazowej immersji, na jaką w Kościele zachodnim zezwolił Synod w Toledo w 622 roku, oznaczała, że formuła chrztu wypowiedziana nad kandydatem w chwili szafowania sakramentu musiała być inwokacją trynitarną, w dodatku już dobrze ukształtowaną w tradycji. Po VII wieku w odpowiedziach Magisterium Kościoła na konkretne zapytania w sprawie ważności chrztu (np. pismach IX-wiecznego papieża Mikołaja I do Bułgarów) znajdowały się odniesienia do chrztów „w imię Jezusa” konkretnych grup osób. Odpowiedzi papieży nie są jednorodne, gdyż każdy z takich przypadków wymagał osobnych studiów. Ważność analizowanych chrztów zależała od intencji szafarza, intencji przyjmującego chrzest oraz wyznawanej przez nich doktryny. Te pojawiające się we wczesnym średniowieczu kazusy są już reliktami wobec generalnej 
i utrwalonej praktyki używania formuły chrzcielnej z wezwaniem Trzech Osób Boskich.

Rozwój wczesnochrześcijańskiej teologii, w tym doktryny trynitarnej, dokonywał się zarówno w aspekcie pozytywnym (jako skutek naturalnych badań nad Pismem), jak i negatywnym (polemika z pojawiającymi się herezjami). Te dwa czynniki wzmagały, intensyfikowały i ożywiały wysiłek intelektualny myślicieli Kościoła. Wysiłek - należy dodać - okraszony wiarą. Kształtowanie się formuły trynitarnej chrztu jest jednym z dowodów nieustanej auto-aktywizacji Kościoła w procesie odkrywania Prawdy.

\section{Summary}

\section{From the baptism "in the name of Jesus" to the trinitarian baptismal formula}

Hypothesis of a possible interpolation of the end of Matthew 28:19-20 as well as the originality of the formula of baptism "in the name of Jesus (described in Acts) in relation to the Trinitarian formula has initiated, in the end of $19^{\text {th }}$ century, a considerable scientific discussion among mainstream theologians of Christian faith that lasts for several decades. The above issue both in the historical aspect of the debate and the current knowledge is the subject of this publication. First part of the article gives a general view of the main research positions on the question of development of the formula of baptism. Then - based on the analysis of selected post-Apostolic texts and the documents of those Church Fathers whose texts have shown the problem of the two formula of baptism the authors present the development of the Trinitarian baptism form. In order to deepen the understanding of the discussed issue the history of the doctrine of the Church, the history of Christianity and lego-political realities of the Late Antiquity has been also taken into account.

In the discussion the authors present the view that the Trinitarian formula derived from a fragment of Matthew 28: 19-20 is an editorial intervention, which can be dated on the second or third century AD. The authors claim that the formula of baptism "in the name of Jesus" was the oldest baptismal invocation, preceded by a confession of faith which have contained the whole Judeo-Christian tradition of the acceptance of the mystery of the Trinity. Since post-Apostolic period the transition from the Christocentric formula of baptism to the Trinitarian one appeared in the Church and developed in an evolutionary way. Number of factors, such as: heretical movements and theological errors as well as close relationship of the liturgy of baptism with the public 
creed had contributed to such evolution. The development of the doctrine of the Trinity expressly formulated as a dogma at the Council of Nice (325 AD) was the final impetus to spread the Trinitarian formula of baptism over the universal Church and caused the gradual expiration of the Christocentric baptismal formula.

Keywords: "Baptism in Jesus' Name”, baptism Formula, Validity of Baptism, Trinitarian Formula

\section{Bibliografia}

[b. a.], ... to avoid using masculine language of God, „Roman Replies and CLSA Advisory Opinions" 1990, s. 91-93.

Antologia literatury patrystycznej, t. 1, przeł. i oprac. M. Michalski, Warszawa 1975. Baptême, [w:] Dictionnaire d'archèologie chrétienne et liturgie, ed. F. Cabrol, vol. II, Paris 1910, s. 338-342.

Baptism, [w:] Catholic Encyclopedia. An international work of reference on the constitution, doctrine, discipline, and history of the Catholic Church, ed. E. A. Pace et al., vol. 2, www.newadwent.org/cathen/00001a.htm (10.08.2014).

Bazyli Wielki, Listy, wybor, przekł. z jęz. grec., wstęp, przypisy i indeksy W. Krzyżaniak, Warszawa 1972.

Beek A. van de, Heretical baptism in debate, „In die Skriftlig” 2009 nr 43 (3), s. 537-561.

Brekelmans A., Wyznania wiary w pierwotnym Kościele. Powstanie i funkcje, tłum. B. Skóra SDV, „Concilium. Międzynarodowy Przegląd Teologiczny” 1970 z. 1-5, s. $28-35$.

Burnet T., De Fide et Officiis Christianorum, Hale 1786.

Campenhausen H., von, Taufe auf den Name Jesu?, „Vigiliae Christianae” 25 (1971), s. 1-16.

Carpenter H. J., Creeds and baptismal rites in the first four centuries, „The Journal of Theological Studies" 44 (1943), s. 367-377.

Carrol W. H., Historia chrześcijaństwa, t. 1, Narodziny chrześcijaństwa, tłum. J. Morka, Wrocław 2009.

Chrzest, [w:] Encyklopedia katolicka, t. III, red. F. Gryglewicz, R. Łukaszyk, Z. Sułowski, Lublin 1976, s. 354.

Chase F. H., The Lord's command to baptize (St. Matthew XVIII, 19), „Journal of Theological Studies" 1905 nr VI (24), s. 481-512, www.biblicalstudies.org.uk/ pdf/jts/006_481.pdf (12.09.2014).

Congregatio pro Doctrina Fidei, Responsa ad proposita dubia de validitate baptismatis, „Notitiae” 45 (2008) nr 3-4, s. 135. 
Conybeare F. C., The Eusebian form of the text of Matthew 28:19, „Zeitschrift für Neutestamentlich Wissenchalf" 1901, s. 275-288.

Crehan J. SJ, Early Christian baptism and the creed, London 1950.

Cuneo B. H., The Lord's command to baptise. An historico-critical investigation with special references to the work of Eusebius of Caesarea, Washington 1923.

Dokumenty synodów od 50 do 381 roku, red. A. Baron, H. Pietras, Kraków 2006 (Źródła Myśli Teologicznej, 37; Synody i Kolekcje Praw, 1).

Dzieje Ksantypy i Polikseny, [w:] Apostołowie, cz. 2, Barttomiej, Filip, Jakub Mniejszy, Jakub Większy, Judasz, Maciej, Mateusz, Szymon i Juda Tadeusz ewangeliści, uczniowie pańscy, pod red. M. Starowieyskiego, współpr. K. Bardski, Kraków 2007 (Apokryfy Nowego Testamentu, 2).

Encyclopaedia Biblica: A critical dictionary of the literary, political and religion history, the archeology, geography and natural history of the Bible, ed. T. K. Cheyne, J. Sutherland Blacked, Toronto 1899.

Encyclopédiè théologie, t. 33, Dictionnaire de théologie dogmatique, vol. I, ed. abbé Pierrot, J. P. Migne, Paris 1850.

Ferguson E., Baptism in the early Church. History, theology and liturgy in the first five centuries, Cambridge 2009.

Fiedorowicz M., Teologia ojców Kościoła: podstawy wczesnochrześcijańskiej refleksji nad wiara, przekł. W. Szymona, Kraków 2009.

Flusser D., The conclusion of Matthew in a New Jewish Christian Source, „Annual of the Swedish Theological Institute" 5 [1966-1967], s. 110-119.

Gnilka J., Paweł z Tarsu. Apostoł i świadek, przekł. W. Szymona OP, Kraków 2001.

Gnilka J., Teologia Nowego Testamentu, tłum. W. Szymona OP, Kraków 2002.

Green H. B. CR, Matthew 28:19, Eusebius, and the lex orandi, [w:] The making of orthodoxy, ed. R. Williams, Cambridge 1989, s. 124-141.

Grün A. OSB, Chrzest. Początek nowego życia, tłum. G. Sowiński, Kraków 2005.

Ireneusz z Lyonu, Adversus haereses, texte et traduction par A. Rousseau, L. Doutreleau, Paris 1979 (Sources Chrétiennes, 264).

Ireneusz z Lyonu, Wykład nauki apostolskiej, tłum. i oprac. W. Myszor, Kraków 1997 (Źródła Myśli Teologicznej, 7).

Jenson R. W., The Triune God. Systematic theology, vol. I, Oxford 1997.

Justyn Męczennik, Apologia, [w:] Pierwsi apologeci greccy. Kwadratus, Arystydes $z$ Aten, Aryston $z$ Pelli, Justyn Męczennik, Tacjan Syryjczyk, Milcjades, Apolinary $z$ Hierapolis, Teofil z Antiochii, Hermiasz, przeł. L. Misiarczyk, J. Naumowicz, Kraków 2004, s. 207-270 (Biblioteka Ojców Kościoła, 24).

Kavanagh A., The shape of baptism, the rite of Christian initiation, Collegeville MN 1991.

Kelly J. N. D., Early Christian creeds, London-New York 1972. 
Kosmala H., The conclusion of Matthew, „Annual of the Swedish Theological Institute" 4 [1965], s. 132-147.

Kudasiewicz J., Jezus historii a Chrystus wiary, Lublin 1987 (Jak Rozumieć Pismo Święte, 3).

Lee S., Eusebius, bishop of Cesarea in the Teophania, Cambridge 1843.

Majewski M., Imię Jezusa, „Posłaniec Serca Jezusowego” 2005 [nr 9] wrzesień, www. psj.net.pl/?0509, artykul,ImieJezusa (10.08.2014).

Martineau J., The seat of authority in religion, London 1890.

Miller L. F., The formula of baptism in the early Church, „The Catholic Historical Review" 10 (1925) nr 4, s. 515-535.

Origenis opera omnia, Paris 1862 (Patrologia Latina, ed. J. P. Migne, Paris 18441855).

Pelikan J., Powstanie wspólnej tradycji (100-600), tłum. M. Höffner, red. J. Żelazny, Kraków 2008.

Pierwsi świadkowie. Pisma Ojców Apostolskich, red. W. Zega, tłum. A. Świderkówna, przyp. M. Starowieyski, Kraków 2010.

Pressencé E., de, Early years of the Christian church. The apostolic era, tłum. na j. ang. A. Harwood, vol. II, New York 1870.

Romaniuk K., Sakramentologia biblijna, Warszawa 1994.

Sakrament Chrztu znakiem jedności. Deklaracja Kościołów w Polsce na progu Trzeciego Tysiaclecia, Warszawa 2000, www.ekumenia.pl/czytelnia/dokumenty-ekumeniczne/sakrament-chrztu-znakiem-jednosci/ (19.12.2014).

Stenzel A., Il battesimo. Genesi e evoluzione della liturgia battesimale, Alba 1962.

Tertulian, De baptisimo, ed. B. Luiselli, Torino 1969 (Corpus Scriptorum Latinorum Paravianum, 32).

The devil at baptism. Ritual, theology and drama, red. H. A. Kelly, New York-London 1995.

Tomasz z Akwinu: Summa theologiae, www.corpusthomisticum.org/iopera.html\#OM (9.12.2014).

[b. a.], Trinitarian baptism, www.catholic.com/tracts/trinitarian-baptism (10.08.2014).

Turner P., Ages of initation. The first two Christian millenia, Collegeville MN 2000.

Whitaker E. C., Documents of the baptismal liturgy, wyd. I, London 1960.

Whitaker E. C., Documents of the baptismal liturgy, Minnesota 1970.

Whitaker E. C., History of baptismal formuta, "The Journal of Ecclesial History” 16 (1965), s. 1-12.

Young's literal translation of the Holy Bible, Edinbourgh 1862. 